\title{
O Aurélio era preto: trabalho, associativismo e capital relacional na trajetória de um homem pardo no Brasil Imperial e Republicano
}

\author{
The Aurelius was black: Work, associations and \\ relational capital in the trajectory of a brown man \\ in the Empire and the Brazilian Republic
}

El Aurelio era negro: trabajo, asociamiento y capital relacional en la trayectoria de un hombre pardo en el Brasil del Imperio y Republicano

Paulo Roberto Staudt Moreira ${ }^{\mathrm{a}}$

\begin{abstract}
Resumo: Este artigo analisa as inserções profissionais e associativas de um homem negro, durante o Império e primeiros anos da República, no Brasil, percebendo as posições ocupadas por ele em redes sociais e políticas que lhe possibilitaram ascensão e prestígio. Percebemos que Aurélio Viríssimo de Bittencourt constituiu uma autorrepresentação étnico-racial de pardo, percebendo-se como equidistante do mundo dos brancos e do cativeiro, mundos esses nos quais convivia e circulava. O seu pertencimento racial e social pode ter lhe colocado alguns obstáculos, mas também deu-lhe um posicionamento ambivalente de mediador entre diferentes grupos étnicos e sociais.
\end{abstract}

Palavras-chave: Escravidão. Educação. Irmandades.

Abstract: This article analyzes the trade and association inserts a black man during the Empire and early Republic, Brazil, noting the positions held by him in social and political networks that enabled him to rise and prestige. We realize that Virissimo Aurélio de Bittencourt was a racial-ethnic self-representation brown, perceive themselves as equidistant from the white world, and from captivity, in which these worlds lived and circulated. Your racial and social belonging may have put you some obstacles, but also gave him an ambivalent position of mediator between different ethnic and social groups.

Keywords: Slavery. Education. Religious brotherhoods.

${ }^{\text {a }}$ Professor da Universidade do Vale do Rio dos Sinos (UNISINOS). Doutor em História, bolsista de Produtividade em Pesquisa do CNPq - Nível 2.<moreirast@terra.com.br>. 
Resumen: Este texto analiza las inserciones profesionales y asociativas de un hombre negro, en el período del Imperio y primeros años de la República de Brasil, subrayando las posiciones por él ocupados en las redes sociales y políticas. Dichas posiciones le han posibilitado ascenso político y prestigio. Hemos percibido que Aurélio Viríssimo de Bittencourt ha constituido su auto representación étnica y racial de mestizo pardo, poniéndose en una posición equidistante del mundo de los blanco e del cautiverio, mundos por los cuales circulaba y tenía convivencia. $\mathrm{Su}$ pertenencia racial y social puede haberle colocado algunos tropiezos, pero a la vez, le ha dado una posición ambivalente de mediador entre distintos grupos étnicos y sociales.

Palabras clave: Esclavitud. Educación. Hermandades.

"O Aurélio era preto, como o Gonçalves Crespo e o Cruz e Souza; quero dizer, não tão retinto como o conselheiro Rebouças ou o professor Hemetério, mas daquela pretidão discreta de Luiz Gama, limpa e bonita como a pretidão de amor que o Camões diz que bem merecia ser trocada pela alvura de Vênus [...]."

(TEIXEIRA, 1920, p. 214)

Em 1903, passando dos sessenta e seis anos de idade, o Barão Homem de Mello, ou melhor, Francisco Inácio Marcondes Homem de Mello, ainda mantinha os olhos sobre o Rio Grande do Sul, onde residiam alguns de seus velhos amigos. Entre 22 de janeiro de 1867 e 13 de abril do ano seguinte, Homem de Mello foi Presidente dessa Província sulina, quando reestruturou o $3^{\circ}$ Corpo do Exército, peça importantíssima na guerra movida contra o Paraguai. Segundo ele mesmo escreveu em seu relatório de 1867, apresentado à Assembleia Provincial:

Na luta grandiosa que o Império sustenta contra o Governo do Paraguay, a história dará honroso testemunho, de que coube a Província de São Pedro do Rio Grande do Sul, o principal quinhão nesta glória, reunindo e organizando em seu seio novos elementos, com que se empreendesse um golpe decisivo sobre o inimigo. Tal foi a organização do $3^{\circ}$ Corpo do Exército, hoje em operações contra o governo do Paraguay. ${ }^{1}$

\footnotetext{
${ }^{1}$ AHRS - Fala do Presidente da Província Dr. Francisco Inácio Marcondes Homem de Melo à
} Assembleia Legislativa Provincial na $2^{\mathrm{a}}$ sessão da $12^{\mathrm{a}}$ legislatura em setembro de 1867, p. 5. 
O primeiro e único Barão Homem de Mello era filho do Capitão da Guarda Nacional Francisco Marcondes Homem de Mello e Ana Francisca de Mello e, em 1858, formou-se na Faculdade de Direito do Largo de São Francisco. Vinculado ao Partido Liberal, foi vereador, professor concursado de "História Universal" do Colégio Dom Pedro II (no Rio de Janeiro), Presidente das Províncias de São Paulo, Ceará e Bahia, além do Rio Grande do Sul, Diretor do Banco do Brasil, Ministro do Império no $28^{\circ}$ Gabinete, Deputado Geral na $17^{\mathrm{a}}$ Legislatura, Conselheiro Imperial, Veador da Casa Imperial e Dignitário da Imperial Ordem da Rosa, Sócio-Benemérito do Instituto Histórico e Geográfico Brasileiro (admitido em 1859). Com a proclamação da República, abandonou a vida pública.

Em 1903 ele residia no Rio de Janeiro, e em 10 de setembro enviou um cartão para seu "prezado amigo" Aurélio Viríssimo de Bittencourt, pedindo-lhe o favor de visitar em seu nome o General Xavier do Vale, que constava estar doente ${ }^{2}$. Viríssimo era então Chefe de Gabinete do Presidente do Estado Antonio Augusto Borges de Medeiros, cargo que já ocupara na gestão anterior, de Júlio Prates de Castilhos. Mesmo que o público e o privado se confundam na política brasileira, a forma de tratamento usada por Homem de Mello - prezado amigo - indica que ele estava acionando lembranças mútuas já antigas e revestindo a relação entre ambos de uma intimidade que extrapolava (reforçando) o políticopartidário. Ademais, o pedido do Barão foi feito em um diminuto cartão de apresentação, denotando que o afeto entre eles prescindia de etiquetas mais demoradas ${ }^{3}$. Tratava-se de um favor alicerçado em uma relação antiga, de dois velhos correligionários do Partido Liberal, dos tempos imperiais.

Provavelmente Aurélio não se furtou a prestar a gentileza solicitada pelo Barão, até porque ele e o General Xavier do Vale residiam razoavelmente próximos. Aurélio em uma casa assobradada na rua General Bento Martins, ${ }^{\circ} 53$ e o General em um prédio térreo, de uma porta e 3 janelas de frente, no $\mathrm{n}^{\circ} 95$ da rua Coronel Genuíno, ambos endereços no centro da capital do Estado. A ansiedade do Barão pela saúde do General era plenamente justificada. Menos de um ano depois, em 12 de maio de 1904, o General Joaquim Antonio Xavier do Vale falecia, deixando a viúva Paula do Loreto Carneiro Viana do Vale e

\footnotetext{
${ }^{2}$ IHGRS - APAVB - Pasta 2 - Estado e Anexos.

${ }^{3}$ Não deve escapar à perspicácia do pesquisador o que Norbert Elias (1993, p. 17) chamava de "sutilezas do intercâmbio social", desveladas através da "maneira de cumprimentar e de escolher as palavras".
} 
cinco filhos, todos legítimos e maiores: Maria Augusta Xavier do Vale (solteira), o Tenente Joaquim Xavier do Vale (casado com Dona Litizia Castilhos do Vale), Ana Efigênia Xavier do Vale Soares (casada com Felipe Paula Soares), Antonio Xavier do Vale (solteiro) e Luiz Xavier do Vale (solteiro) ${ }^{4}$.

Mas naquele mesmo mês e ano em que o Barão Homem de Mello se correspondeu com Aurélio, o General Xavier do Vale também procurou se servir de um obséquio do mesmo indivíduo, conformando um triângulo relacional. Em carta reservada de 25 de setembro de 1903, o Deputado Federal Joaquim Antonio Xavier do Vale, afirmava categoricamente:

Ponto nos i i e cartas sobre a mesa. Falei-vos com franqueza, que tenho a firme convicção de que a política deste estado é sabiamente dirigida por vós e pelo Coronel Marcos de Andrade. O amigo dirige a política administrativa e o Cel. Marcos a eleitoral. Assim é que, aproveitando estes dois auxiliares, o nosso incomparável chefe Júlio habilmente vai fazendo a felicidade do Rio Grande e domina a política da União (IHGRS - APAVB).

O General e Deputado Xavier do Vale pedia que Viríssimo intercedesse junto a Júlio de Castilhos, pedindo a indicação de seu filho para o cargo de Inspetor da Alfândega do Rio Grande, dizendo que a nomeação dependia apenas da vontade de Aurélio.

A nomeação de Luiz é de grande vantagem, porque, além de inteligente e honesto, há de cumprir as ordens dos chefes castilhistas. Prometeste-me que escreveria ao nosso querido chefe Castilhos, que estava convalescendo na chácara e que, conforme a resposta, me daria ciência e passaria telegrama a Pinheiro Machado para indicar essa nomeação ao Dr. Rodrigues Alves, protetor de meus filhos [...]

Prometes-te-me proteger meu pimpolho Luiz, peço o cumprimento de vossa promessa e se consultardes com calma a vossa consciência, tendo em memória a imagem de vosso bom pai, meu saudoso compadre e amigo, haveis de reconhecer que me assiste o direito da vossa gratidão.

\footnotetext{
${ }^{4}$ Os bens do General se resumiam a dois imóveis, o prédio da Coronel Genuino (avaliado em 20 contos de réis) e uma meia água $\mathrm{n}^{\circ} 216$, sito a rua João Alfredo, de uma porta e uma janela de frente (estimado em 1 conto e 200 mil réis. APERS $-1^{\circ}$ Cartório do Cível e do Crime - Inventário, Auto 709, Inventariado: Joaquim Antonio Xavier do Valle, Inventariante: Paula do Loreto Carneiro Viana do Vale, data:1904. O Brigadeiro Graduado Xavier do Vale nasceu no Mato Grosso em 1824 e assentou praça voluntariamente em 11.03.1837, sendo reformado no posto de General de Brigada efetivo, com as vantagens do decreto 18 , de 17.10.1891, pelo Decreto $\mathrm{n}^{\mathrm{o}} 178$ do Poder Legislativo de 16.09.1893. AHEx - Pasta IV-21-40. Agradeço ao historiador Miquéias Mügge por generosamente fotografar esta fé-de-ofício, durante suas pesquisas no Arquivo do Exército (RJ).
} 
Talvez a fragilidade do estado de saúde do General o deixasse ainda mais preocupado em acionar seus contatos para resolver o futuro de seu pimpolho e caçula Luiz Xavier do Vale. Nessa ânsia, valia a afirmação de fidelidade ao castilhismo e ao seu líder máximo, e mesmo a reivindicação de um direito de gratidão, justificado pelo compadrio e amizade com o pai do destinatário. Vale também destacar o elogio feito pelo Deputado a importância de Aurélio na política local, que, segundo ele, era o principal responsável pela gestão pública regional, principalmente na questão administrativo-burocrática ${ }^{5}$.

Refletindo sobre a "dimensão sociológica e cultural do clientelismo", o historiador José Murilo de Carvalho (2000, p. 2) analisou a correspondência passiva (recebida) de Rui Barbosa durante os quatorze meses em que ocupou o Ministério da Fazenda (de 15 de novembro de 1889 a 21 de janeiro de 1891). Este acervo toma maior relevância, pois foi gerado em um momento de transição política, da "passagem de um sistema que muitos condenavam como sendo de privilégios e de patronagem, para outro exaltado pelos adeptos como baseado na igualdade e no mérito". Das 2.529 correspondências (cartas, cartões, telegramas), 1.013 , cerca de $40 \%$ do total, referem-se a pedidos de favor, em forma de pedidos para si ou para outrem, os famosos empenhos. Analisando a razão clientelista, Carvalho (2000, p. 9) percebe que três justificativas eram as mais usadas para se obter o favor ministerial: competência $(34,9 \%)$, amizade/parentesco $(27,6 \%)$ e a necessidade (18,8\%). Alegações embasadas em razões político-partidárias, por estranho que pareça, eram uma minoria (2000, p. 10).

A correspondência mostra, sobretudo, o profundo enraizamento social do clientelismo político, que pode ser visto como troca entre partes desiguais envolvendo bens públicos. A troca desigual no campo político era uma extensão de trocas desiguais no campo social. O clientelismo político enraizava-se em uma sociedade hierárquica composta de protetores e protegidos. $\mathrm{O}$ patronato hierárquico social era transferido para o campo político, o governante tornava-se o patrão, o protetor, o pai. Pedia-se que Rui fosse patrono e protetor. Os clientes definiam-se como inferiores

\footnotetext{
${ }^{5}$ O pimpolho Luiz tinha 27 anos em 1903 e foi batizado em 31.03.1876 na Igreja do Rosário. Os avós paternos eram o Alferes Antonio Xavier do Valle e Ana Efigênia Xavier do Vale e os avós maternos o Conde de São Simão e Maria Augusta da Glória. Foram padrinhos o Marechal de Campo Barão da Penha (representado pelo procurador Dr. Manoel Martins dos Santos Penna) e Mariana de Lima e Silva Penna (filha do General João Manoel de Lima e Silva). (AHCMPA - Livro de Batismos de Livres do Rosário no 8 e 9, folhas 106 e 131). Agradeço a arquivista e historiadora Vanessa Gomes de Campos pela ajuda com a documentação eclesiástica.
} 
- criados, servos, súditos, veneradores, respeitadores - e como leais, dedicados, fiéis, obrigados. Mesmo quando se diziam amigos e colegas, a qualificação quase invariavelmente vinha acompanhada de um complemento hierárquico e da promessa de lealdade. A inferioridade justificava o direito à proteção, a lealdade era a promessa de retribuição da proteção esperada. Os valores republicanos de igualdade e democracia não podiam germinar em tal contexto. O novo cidadão continuava sendo doutor e general, ou criado e súdito, dependendo de sua posição social (Carvalho, 2000, p. 20).

Ele destaca que um traço importante de nossa cultura política é, justamente, a visão do estado como protetor "benevolente e paternalista, cuja obrigação é proteger os pobres", e que esta concepção estava profundamente enraizada no pensamento positivista ortodoxo. Mesmo com estas continuidades, Carvalho (2000, p. 21) defende que existia uma tensão no sistema: "Começava a surgir a ideia da necessidade de burocratizar e racionalizar o serviço público, libertando-o da prisão patrimonial".

Relendo com atenção o cartão do General Xavier do Vale dirigido ao secretário Aurélio Viríssimo de Bittencourt, notamos que nele existia uma espécie de explícito hibridismo. Ele agrega às qualidades meritórias de seu filho (inteligente e honesto) a filiação política ao castilhismo (há de cumprir as ordens dos chefes castilhistas), mas, ao mesmo tempo, clama pela relação que estabelecera com o pai de Aurélio (meu saudoso compadre e amigo), na melhor tradição das relações familiares oitocentistas. A ênfase aos méritos do candidato e a sua afeição política-ideológica com os governantes locais, não descarta a via fecunda da familiaridade, do empenho apoiado numa solidária intimidade. ${ }^{6}$

Reencontraremos estes três personagens mais adiante em nossa narrativa, quando as suas vidas se mesclaram, talvez pela primeira vez, décadas antes.

$$
* * *
$$

\footnotetext{
${ }^{6}$ Aliás, o fervor castilhista da família não era muito antigo, pois um dos filhos do General, Paulo, nascido em 14/11/1873, foi batizado na Igreja das Dores em 31/10/1874, tendo como padrinhos o então deputado liberal Dr. Gaspar Silveira Martins e sua esposa Adelaide Coutinho da Silveira Martins (AHCMA - Livro de batismos de Livres das Dores, folha 135v).
} 
A epígrafe deste artigo foi escrita pelo literato e jornalista Múcio Scévola Lopes Teixeira ${ }^{7}$ e faz parte de seu livro intitulado Os Gaúchos. As ironias deste trecho eram voltadas ao pardo Aurélio Viríssimo de Bittencourt que, ao morrer em 1919, era insigne representante do funcionalismo público regional ${ }^{8}$.

A cor de Aurélio ou a relação de sua epiderme com a sua positiva ascensão social e profissional parece ter fascinado os seus contemporâneos. Indivíduos que se autorreferenciavam como negros e fundaram periódicos voltados a defesa dos direitos deste grupo étnico, usaram Aurélio como exemplo de uma trajetória de sucesso (Santos, 2008 e 2008b). Sujeitos como Múcio Teixeira, que denuncia nesse seu texto uma visão etnocêntrica, também tentava entender como um preto chegou tão longe.

Aurélio Viríssimo de Bittencourt nasceu em $1^{\circ}$ de Outubro de 1849 em Jaguarão, cidade localizada na fronteira brasileira com o Uruguai. Era filho da parda Maria Julia da Silva e do piloto da Marinha Hypólito Simas de Bittencourt ${ }^{9}$.

Este artigo pretende analisar as inserções profissionais e associativas de Aurélio, percebendo as posições ocupadas por este indivíduo não branco em redes sociais e políticas que lhe possibilitaram ascensão e prestígio. Percebemos que Aurélio Viríssimo de Bittencourt desde cedo constituiu uma autorrepresentação étno-racial de pardo, percebendo-se como um indivíduo equidistante do mundo dos brancos e do cativeiro. Mundos esses nos quais convivia e circulava. O pertencimento racial e social de Aurélio pode ter lhe colocado alguns obstáculos, mas também deu-lhe um posicionamento ambivalente de mediador entre diferentes grupos étnicos e sociais. O pardo Aurélio atuou como um mediador cultural ou étnico já que circulava entre diferentes culturas e etnicidades.

\footnotetext{
${ }^{7}$ Múcio Teixeira nasceu em Porto Alegre (13.09.1857) e faleceu no Rio de Janeiro (08.08.1926) (Villas-Bôas, 1974, p. 509-510).

${ }^{8}$ Segundo a historiadora Hebe Mattos (2000, p. 17): “'Pardo' foi inicialmente utilizado para designar a cor mais clara de alguns escravos, especialmente sinalizando para a ascendência européia de alguns deles, mas ampliou sua significação quando se teve que dar conta de uma crescente população para a qual não mais era cabivel a classificação de 'preto'ou de 'crioulo', na medida em que estas tendiam a congelar socialmente a condição de escravo ou ex-escravo. A emergência de uma população livre de ascendência africana - não necessariamente mestiça, mas necessariamente dissociada, já por algumas gerações, da experiência mais direta do cativeiroconsolidou a categoria 'pardo livre' como condição linguística necessária para expressar a nova realidade, sem que recaísse sobre ela o estigma da escravidão, mas também sem que se perdesse a memória dela e das restrições civis que implicava".

${ }^{9}$ Simas de Bittencourt faleceu em 07.01.1884 em Porto Alegre, ocupando o posto de Capitão Tenente da Armada Brasileira. AMRJ - $3^{\circ}$ Livro Mestre dos oficiais da Armada Nacional Imperial, folhas 223-4; APAVB - Pasta 2 - Estado e Anexos.
} 
A bagagem que Aurélio trouxe de Jaguarão (de nascimento e de cor, conforme ele mesmo declarou), acrescida das alianças que fomentou através da sua inserção em redes diversas, redundou em um posicionamento privilegiado. Esse seu encargo de mediador, dependendo do papel social que representava, poderia assumir um perfil mais notadamente étnico, político ou religioso. Sem esquecer que estes perfis carecem de significado se analisados de forma estanque, sem uma perspectiva dialógica ${ }^{10}$.

Atualmente, estudar um indivíduo significa investigar os seus vínculos, as suas afetividades, afinidades e animosidades. Tratar de um indivíduo não é mais simplesmente enaltecer a sua relevância política e a autonomia e repercussão de seus atos. Fazer emergir historicamente um indivíduo é localizá-lo na interdependência de suas relações, sob os mais diversos prismas.

Só a conscientização da autonomia relativa dos planos e ações individuais que se entrelaçam, da maneira como o indivíduo é ligado pela vida social a outros, permite uma compreensão mais profunda do próprio fato da individualidade. A coexistência de pessoas, o emaranhado de suas intenções e planos, os laços com que se prendem mutuamente, tudo isso, muito longe de destruir a individualidade, proporciona o meio no qual ela pode desenvolverse. Estabelece os limites do indivíduo, mas, ao mesmo tempo, lhe dá maior ou menor raio de ação. $\mathrm{O}$ tecido social, nesse sentido, forma o substrato a partir do qual e para dentro do qual o indivíduo gira constantemente e tece suas finalidades na vida. Esse tecido e o curso real de sua mudança como um todo, porém, não são obra da intenção nem do planejamento de ninguém (Elias, 1993, p. 289).

$$
* * *
$$

\footnotetext{
${ }^{10}$ Conforme Imízcoz (2001, p. 242) o capital relacional é um elemento-chave (muito mais do que os recursos materiais) no entendimento de quais indivíduos podem exercer este papel: "esta posición de mediador hacía de él un hombre necesario, buscado por los dependientes, y le valia la estima $y$ el reconocimiento de sus favorecidos". Carvalho (2005, p. 244) estudando os populares em uma zona de forte imigração europeia, destacou os vendeiros, taberneiros ou bolicheiros como mediadores culturais: "Não que fossem criaturas caracterizadas pela ambigüidade cultural, mas como tinham que atender clientela com elevado grau de heterogeneidade acabavam por mapear com competência as diferenciações existentes entre os grupos com os quais habitualmente conviviam". Contemplando hibridismos, mestiçagens ou circularidades culturais, ver; Gruzinski (2001), Burke (2003) e Bakhtin (1993). Várias pesquisas que enfocam trajetórias individuais ilustram casos de mediadores étnicos, ver, por exemplo, Reis (2008). Marcos Witt (2001) e Jonas Vargas (2007) investigam indivíduos que intermediavam ou conectavam diferentes instâncias de poder (paroquial, provincial e imperial). Ver também: Levi, 2000; Costa, 2011; Venâncio, 2009.
} 
O menino Aurélio ficou com sua mãe em Jaguarão até os 10 ou 12 anos, quando se mudou para Porto Alegre, à requisição de seu pai, para estudar. Maria Júlia da Silva faleceu em 1874, aos 40 anos de idade, e até onde sabemos, mãe e filho não mais se reencontraram depois de despedirem-se, quando Aurélio mudou-se para a capital. Aurélio só retornou a Jaguarão em circunstâncias completamente diferentes, em 1910, já Coronel da Guarda Nacional e representando o Presidente do Estado Carlos Barbosa Gonçalves, escolhido como paraninfo da formatura da primeira turma de bacharéis em Ciências e Letras do Ginásio Espírito Santo ${ }^{11}$. Depois de ser conduzido em carro descoberto da "Pensão Susini" ao teatro ${ }^{12}$, o Coronel Aurélio fez uma "brilhante alocução" tratando dos "benefícios de uma boa educação". Achamos pouco provável que, religioso como era, Aurélio tenha se esquivado de ir ao cemitério rezar e depositar algumas flores no túmulo de sua mãe, com quem se correspondia quando, ainda menino, foi-se com o pai.

Sendo o pai marinheiro e Jaguarão localizada convenientemente em redes fluviais e lacustres, é provável que o pardinho Aurélio tenha chegado a Porto Alegre em um vapor, atracando no movimentado porto local. Porto Alegre e Jaguarão equivaliam-se na proporção escrava de seus habitantes - eram cerca de $1 / 4$ em ambas, mas a capital da Província tinha três vezes mais habitantes, 43.998 e 13.762, respectivamente (Moreira, 2010).

Hypólito Simas de Bittencourt foi promovido a $2^{\circ}$ Tenente da Armada por decreto de 9 de janeiro de 1858 e desde outubro do ano anterior estava servindo na Província do Mato Grosso. Por Aviso de 23.03.1861 foram-lhe concedidos 3 meses de licença, "com soldo, para ir a Província do Rio Grande tratar dos seus interesses", quando talvez tenha ajudado na mudança e instalação do filho Aurélio na Capital. A vida itinerante de marinheiro, porém, não permitia que Hypólito cuidasse efetivamente de seu filho, o qual provavelmente ficou a cargo de sua irmã, Leocádia Virginia de Castro.

\footnotetext{
${ }^{11}$ Gymnasio Espírito Santo. Equiparado ao Gymnasio Nacional por decreto no 6818 do dia 9 de janeiro de 1908. Jaguarão. Estado do Rio Grande do Sul. Anno lectivo de 1910. Distribuição Solemne dos Premios. 17 de Dezembro de 1910. Typographia Santa Familia.

${ }^{12} \mathrm{O}$ Teatro aqui descrito é o Teatro Esperança, inaugurado em 13 de janeiro de 1897, que atualmente passa por restauro e que ainda se preserva como um dos mais antigos do Estado. Começou a ser construído em 1887 com o nome de Teatro 27 de Janeiro, referência a data marcada pela tida "heroica" expulsão das forças uruguaias do partido Blanco em 1865 das terras do município. Mas este prédio do Teatro que começou a ser edificado no período imperial, só seria inaugurado durante o período republicano, no ano de 1897. Com o nome de Teatro Politheama Esperança, o lugar teve como um dos maiores acionistas, Carlos Barbosa Gonçalves, virando um monumento sob os domínios do Partido Republicano e de suas lideranças na cidade. Ver: Franco, 2001; Hessel, 199.
} 
Permeiam o texto deste artigo palavras ou expressões que denotam incerteza, como provavelmente, talvez, quem sabe. Só os historiadores mais arrogantes - e os há! - prescindem de tais engenhosidades narrativas, almejando convencer os desacautelados leitores de que as vicissitudes biográficas que alcançaram, desvelam completamente as tramas nas quais estavam inseridos seus personagens (ver: Davis, 1987 e Ginzburg, 1991). As exíguas provas documentais que manejamos não chegam - nem de perto - para reconstituir as vidas dos que nos dedicamos a estudar e a explicar plenamente suas escolhas, sucessos e desventuras. Afinidades e animosidades são entrevistas parcamente em pistas que as demarcam momentaneamente e não nos permitem extrapolar em demasia os fugazes instantes relacionais que aí afloram. Isso, indubitavelmente, não nos isenta de opinar e construir versões verossímeis.

Adentramos rapidamente neste desvão narrativo para deixar transparente aos leitores que supomos que o pardinho Aurélio tenha recebido cuidados de sua tia Leocádia, com quem provavelmente residisse na casa comprada por seu pai, na rua General Bento Martins, $n^{\circ} 53$, a mesma em que persistia residindo nos idos de 1903. O Capitão Tenente da Armada Brasileira Hypólito Simas de Bittencourt, falecido em 07.01.1884, reconheceu em seu testamento que Aurélio era seu filho natural e nomeou-o como o herdeiro universal de seus bens. A respeito de Leocádia, escreveu ele em seu testamento que ela era a sua única irmã viva, e que:

há muitos anos habita a casa de minha propriedade à rua do General Bento Martins, número 53, onde, quando eu venho a esta capital, paro. Declaro: os trastes, trem de cozinha, louça, mobília, ornamentos de casa e tudo quanto existe na dita propriedade são de minha referida irmã [...] excetuando-se apenas as roupas de que uso. ${ }^{13}$

O Capitão Hypólito legou a casa da Bento Martins $n^{\circ} 53$ e os serviços dos escravos crioulos Apolinário e Maurícia ao usufruto de Leocádia até o momento de sua morte, quando então os cativos deveriam ser alforriados e o imóvel assobradado passar para a propriedade de Aurélio. Hypólito deve ter atrelado a liberdade definitiva de Apolinário e Maurícia à morte de sua irmã, para que eles cuidassem da já cinquentona, viúva e sem filhos Leocádia, mas quem sabe soubesse que, se os legasse

\footnotetext{
${ }^{13}$ APERS - Cartório da Provedoria, 1884, inventário 822, maço 36.
} 
a Aurélio, ele imediatamente os alforriaria, principalmente naquele ano de 1884, quando o movimento abolicionista (que tinha esse pardo como um dos líderes) crescia assustadoramente, principalmente nos centros urbanos da província (Moreira, 2003).

Assim, é plausível que Leocádia tenha cuidado do pardinho Aurélio e que até mesmo, juntos, tenham frequentado as Igrejas de sua devoção. Sabemos que Leocádia concentrava seu fervor religioso em duas irmandades de Porto Alegre, a do Senhor do Bom Fim (no Campo da Várzea) e a das Dores (no centro da capital), frequentando também a Igreja do Senhor dos Passos (na Santa Casa de Misericórdia). Podemos imaginar Aurélio sendo conduzido por sua tia e introduzido por ela nas sociabilidades devocionais de Porto Alegre. Isso combina com o que escreveu Múcio Teixeira (autor da epígrafe desse artigo), que cáustica e ironicamente assim descreveu a trajetória de Aurélio:

Aurélio de Bitencourt começou a sua longa e notável carreira pública partindo de muito baixo até chegar bem em cima. Foi sacristão da igreja das Dores, andando pelas ruas de opa e salva de prata, para recolher as esmolas dos irmãos das almas e crentes da Santa Madre Igreja [...] Como se vê, é um negro de clara sorte na terra $[. .$.$] Casando-se com uma mulher de sua raça, interessante$ e honesta, constituiu um lar respeitável, educando os filhos de maneira a serem recebidos na melhor sociedade, a todos causando fundo sentimento a prematura morte do seu primogênito, herdeiro e continuador do nome paterno, que pouco depois de se formar em Direito fora nomeado juiz de um dos distritos de Porto Alegre (Teixeira, 1920, 214).

Leocádia, já maior de 60 anos, doente, mas em perfeito juízo, ditou e assinou suas últimas vontades em 22 de março de 1887. Disse ser natural de Santa Catarina e viúva de Luiz Beltrão de Miranda e Castro. Deixou legados para a Ordem Terceira de Nossa Senhora das Dores (de Porto Alegre), para as devoções do Senhor do Bonfim (da capital e de Rio Grande) e para as Igrejas do Senhor dos Passos (das mesmas cidades). As terminais e irrevogáveis palavras de Leocádia evidenciam a migração de sua família, natural de Santa Catarina, que procurou oportunidades em Rio Grande e depois veio para a capital da Província ${ }^{14}$.

\footnotetext{
${ }^{14}$ Poderíamos ainda inserir neste roteiro migratório a cidade de Jaguarão, onde o marinheiro Hipólito conheceu a parda Maria Júlia da Silva (e a sua mãe Josefa) e Aurélio ingressou na família e, logo depois, também cumpriu a sina do deslocamento geográfico em busca de sua sorte. Aliás, pesquisando os registros eclesiásticos de Jaguarão, salta aos olhos a quantidade de indivíduos nascidos em Rio Grande que ali foram tentar fortuna.
} 
Não sabemos quando veio para Porto Alegre, mas nas vésperas da abolição ela ainda mantinha relações diretas com a cidade portuária de Rio Grande, seja no aspecto devocional ou com a família de seu falecido marido. Deixou, por exemplo, a Antonio Pedro de Miranda e Castro "morador em Rio Grande", uma apólice da dívida pública (de 1 conto de réis) e os serviços da escrava Salvadora, por tempo de 4 anos, a contar do dia de seu falecimento em diante "e findo o referido tempo será ela considerada livre" 15 .

A alma de Leocádia separou-se de seu corpo em 5 de dezembro do mesmo ano em que ditou seus derradeiros desejos, à uma hora da tarde. Devia ser um dia quente, quem sabe amenizado pela brisa do estuário do Guaíba, ali próximo, quando o testamenteiro e único herdeiro universal de Leocádia, o português José Maria Fernandes Granja, levou o testamento até o Juiz de Direito da Vara da Provedoria Bernardo Dias de Castro Sobrinho, às duas e meia horas da mesma tarde.

Sentimos quando nos imiscuímos afirmativamente nas intimidades familiares de nossos personagens quando, além do que eles nos contam através dos vestígios documentais, com eles nos comunicamos através das ausências e silêncios que nos legaram. Naquele texto, repetimos, onde registrou suas palavras finais e irrevogáveis, Leocádia distribuiu parcimoniosamente seus bens a afilhados, amigos e compadres, ainda mais que declarou não ter parentes ascendentes nem descendentes. Mas, em nenhum momento, mencionou seu sobrinho (natural ou bastardo) Aurélio Viríssimo de Bitencourt ${ }^{16}$.

Podemos conjecturar que Leocádia achasse que seu sobrinho Aurélio, nas vésperas da abolição e da proclamação da República, já tinha a vida ganha, por isso nada lhe legava de bens materiais. Mas o fato de não

\footnotetext{
${ }^{15}$ Em 1861 Antonio Pedro de Miranda e Castro trabalhava na Alfândega de Uruguaiana. Naquela data foi enviada de Porto Alegre uma Comissão de Inspeção de Porto Alegre para investigar o "péssimo estado de fiscalização" em que estava. Miranda e Castro foi um dos inquiridos, atuando como oficial de descarga, exercendo as funções de $3^{\circ}$ escriturário. Em 8 de dezembro de 1861 Antonio Pedro apadrinhou Manoel, batizado em Santa Ana de Uruguaiana, nascido em 5 de outubro do ano anterior, filho de Joaquina, escrava de Joaquina Francisca da Silva. Em 1870 ainda estava naquela alfândega, quando foi suspeito de envolvimento no roubo realizado pelo liberto mina Antonio, o qual fugiu com a amásia Rosa e seus filhos, todos escravos, em direção da fronteira. Em 8 de julho de 1872, ele adotou e perfilou a inocente Adélia, que estava a seus cuidados, nascida em 18 de outubro de 1869. Adélia era filha natural da escrava Felicidade (de Antonio Simões Pires), batizada como livre e apadrinhada na pia batismal pelo Barão de Ijuí e sua esposa. A liberdade de Adélia foi garantida pelo pagamento de 200 mil réis por uma comissão que comemorava a volta do barão do Paraguai, composta do padre Francisco Alves Barroso, Fernando Vieira de Carvalho, Antonio Pedroso de Albuquerque Sobrinho e Pedro Fortunato Ortiz. APERS - Tabelionato de Uruguaiana, Livro 9 de Transmissões de Notas, p. 27; Thompson Flores, 2007, p. 130-131; Moreira, 2011.

${ }^{16}$ APERS - Cartório da Provedoria, maço 72, auto 2213, 1887, testador: Leocádia Virginia de Castro, testamenteiro: José Fernandes Granja.
} 
lhe deixar nem a imagem de um santo e não mencioná-lo sequer, evidencia que, pelo menos naquele momento, não tinha por ele muita simpatia ${ }^{17}$.

Mesmo que nunca saibamos exatamente se o estranhamento entre a tia e seu sobrinho bastardo tinha fundamentos raciais ou meramente financeiros (ou as duas questões atuando conjuntamente), achamos crível que ela o tenha inserido nas sociabilidades devocionais da capital. Com o tempo, porém, Aurélio achou (e formou) a sua própria turma, optando por manifestar sua sólida crença católica em irmandades e Igrejas frequentadas por um público com o qual sentia afinidades, étnicas e sociais ${ }^{18}$.

O documento mais antigo que localizamos da estada de Aurélio em Porto Alegre está no seu acervo particular - custodiado pelo Instituto Histórico e Geográfico do Rio Grande do Sul -, e é uma certidão de 21.11.1861, quando prestou exame no Seminário São Feliciano, em Porto Alegre, sendo aprovado em francês (cum laudi) e geografia ${ }^{19}$. Aurélio continuou seus estudos no Lyceu Dom Afonso, onde em 03.12.1863 prestou exame, sendo aprovado plenamente em Inglês (matérias do $2^{\circ}$ ano), e no dia seguinte simplesmente em Desenho (matérias do $2^{\circ}$ ano). Em 28.11.1864 foi aprovado, também simplesmente, no exame do $1^{\circ}$ ano de latim, $3^{\circ}$ ano de inglês e $2^{\circ}$ ano de desenho. Dois anos após, em 1866, Viríssimo cursava o Lyceu Dom Afonso e pediu que seus professores atestassem sua assiduidade, frequência e aproveitamento, o que foi feito pelos lentes de Matemática (João Batista de Alencastro "com assiduidade e bom comportamento") ${ }^{20}$, Desenho (Ângelo Ther) e

\footnotetext{
${ }^{17}$ Aliás, o oratório "com imagens e pertences" foi deixado para a esposa de seu testamenteiro e herdeiro universal, Amélia da Silva Granja, a qual, junto com a afilhada Clara Virginia de Castro Chacon, ficou com "todos os móveis e utensílios que existirem dentro de minha casa ao tempo de meu falecimento". Outra filha do testamenteiro, também chamada Amélia, ficou com o piano da falecida e uma cama grande. As ácidas interpelações de Leocádia e Aurélio durante o inventário do Capitão Hypólito Simas de Bittencourt indicam que já alguns anos antes os ânimos entre os dois estavam abalados.

${ }^{18}$ Por questões de espaço não trataremos neste artigo das inserções devocionais de Aurélio, mas percebemos que ele, inicialmente, foi assíduo e ativo participante da Irmandade do Rosário e de Nossa Senhora da Conceição. O historiador Mauro Dillmann (2008) estudou três irmandades que funcionavam na capital da Província de São Pedro nos oitocentos - a de São Miguel e Almas, a de Nossa Senhora da Conceição e a de Nossa Senhora do Rosário -, "respectivamente destinadas a brancos, pardos e negros".

${ }^{19} \mathrm{O}$ Seminário São Feliciano foi criado em janeiro de 1855, com 18 seminaristas, em uma casa alugada por Dom Feliciano José Rodrigues de Araújo Prates, primeiro Bispo do Rio Grande do Sul. O prédio do seminário foi só terminado em 1888, tendo as obras começado em 1865 (Oliveira, 1985, p. 106).

${ }^{20} \mathrm{O}$ Coronel João Batista de Alencastro nasceu nesta Província, filho legítimo dos finados Capitão Manoel José de Alencastro e Dona Mara da Luz de Menezes. Era casado com sua sobrinha Maria Delfina de Alencastro, natural de Goiás, filha legítima dos falecidos Coronel Antonio Pedro de Alencastro e Maria da Conceição de Alencastro. Este casal teve apenas um filho, já falecido quando da redação do testamento de ambos, em 15.05.1868 e residiam na rua do Arvoredo, em Porto Alegre. O Coronel faleceu em 19 de julho do mesmo ano. APERS - Cartório da Provedoria, auto 1786, maço 68. Testamento. Testador: João Batista Alencastro. Testamenteiro: Maria Delfina de Alencastro.
} 
Inglês ${ }^{21}$. Em fins de 1867 ele foi aprovado plenamente no exame público de francês em um colégio particular de que era Diretor Jesuíno José de Oliveira e professor Antonio Cabral de Melo. Teve, segundo o professor, "excelente conduta e aproveitamento".

Em 1861, quando estudava latim e geografia no Seminário São Feliciano, Aurélio tinha apenas 12 anos. O acesso de Aurélio à cultura letrada certamente foi uma variável importante nas inserções profissionais que marcaram sua biografia. Assim, não é a toa que ele tenha legado a importância do estudo aos seus filhos e que tenha participado de iniciativas voltadas à extensão da educação aos trabalhadores em geral.

Corria o ano de 1864 quando Aurélio, então com 15 anos, ingressou no mundo das tipografias, empregando-se no Jornal O Mercantil (de propriedade dos irmãos Félix e Francisco Xavier da Cunha) e depois no Jornal do Comércio (fundado pelo pernambucano Luiz Francisco Cavalcanti de Albuquerque). Nesta instância profissional ele percorreu toda a hierarquia funcional: tipógrafo, compositor, remessista, revisor, noticiarista, redator e proprietário.

Consideramos importante esta inserção de Bittencourt no espaço da tipografia, aqui pensado como um campo amplo de integração entre a impressão, a atividade jornalística, a literatura e a militância abolicionista $^{22}$. Configura-se este espaço como um ponto nodal na construção das redes profissionais e afetivas que embasaram suas estratégias de ascensão, socializando-o e integrando-o no seio da jovem intelectualidade provincial. A tipografia, conforme já escreveram alguns historiadores, deve ser vista como um espaço público propício à circulação de ideias ${ }^{23}$. Não era à toa que, segundo o Artigo 303 do Código Criminal, as tipografias tinham que ser registradas nas Câmaras Municipais em códices específicos para isso.

Fontes interessantes para se pensar e localizar quem circulava no espaço das tipografias são as listas de qualificação eleitoral. Essas listas nos trazem informações ricas sobre o universo sócio-profissional do período, como endereço, profissão, filiação e renda. Infelizmente, não temos tantas listas de qualificação eleitoral quanto gostaríamos,

${ }^{21}$ O Lyceu Dom Afonso foi fundado em 1846 e visava a formação de mestres, sendo substituído pela Escola Normal em 1869 (Spalding, 1967).

${ }^{22}$ Os tipógrafos estavam no cerne da gestação de uma pequena classe operária: "Os tipógrafos de Fortaleza negaram-se a executar qualquer impresso que defendesse a escravidão. A Imperial Associação Tipográfica Fluminense, ao ter conhecimento de que entre os seus associados havia um escravo, designou uma comissão para libertá-lo" (Moura, 1988, p. 65).

${ }^{23}$ Segundo a historiadora Maria Helena Machado (1994, p. 148), que estudou os movimentos abolicionistas, dentre os segmentos profissionais urbanos envolvidos na crítica ao escravismo destacaram-se os tipógrafos. 
principalmente pelo pequeno número de arquivos históricos municipais que existem. No AHRS localizamos quatro listas eleitorais de Porto Alegre para a segunda metade dos oitocentos. Observando estas listas no que se refere a qualificação de tipógrafos, temos:

- Lista dos eleitores para a Freguesia de Nossa Senhora Madre de Deus. 3 de março de 1833 - 167 nomes: nesta lista não aparece nenhum tipógrafo;

- Lista geral dos Cidadãos qualificados votantes na Freguesia de Nossa Senhora do Rosário, $2^{\circ}$ Distrito desta Cidade de Porto Alegre. 24 de janeiro de 1850 - 481 nomes: nesta lista não aparece nenhum tipógrafo;

- Lista dos cidadãos qualificados na Paróquia de Nossa Senhora da Madre de Deus. Mesa de qualificação no Consistório da Catedral. 30 de Janeiro de 1865 - 598 nomes: sendo 5 tipógrafos ${ }^{24}$.

Lista geral dos cidadãos qualificados votantes da Paróquia de Nossa Senhora do Rosário da cidade de Porto Alegre no ano de 1880 - 1.450 nomes - nove tipógrafos ${ }^{25}$.

Quando se pensa nas relações nas quais indivíduos como Aurélio estavam inseridos, nos parece natural procurar entendê-las através de sua ligação paterna, mesmo que ilegítima. Como percebemos quando tratamos do processo educativo de Aurélio, seu pai esteve presente no financiamento de sua frequência em seminários e aulas diversas. Quando, entretanto, pensamos na atuação de Aurélio no meio jornalístico, constatamos que as relações não eram apenas as herdadas de seu pai

${ }^{24}$ AHRS - Eleições, maço 2. Em nenhum destes tipógrafos consta especificada a renda: (01) - Estevão Praxedes de Proença Abreu ( $\left.{ }^{\circ} 125\right), 44$ anos, casado, morava no $11^{\circ}$ quarteirão; (02) - Sebastião Eleutério de Medeiros $\left(\mathrm{n}^{\circ} 203\right), 30$ anos, solteiro, morava no $15^{\circ}$ quarteirão; (03) - Eduardo Alves Frazão de Lima ( $\left.{ }^{\circ} 361\right), 25$ anos, casado, morava no $24^{\circ}$ Quarteirão; (04) Valério da Costa Ferreira ( $\left.\mathrm{n}^{\circ} 397\right), 29$ anos, solteiro, morava no $25^{\circ}$ Quarteirão; e (05) - João Gonçalves de Oliveira ( $\left.\mathrm{n}^{\circ} 102\right), 38$ anos, viúvo, desqualificado por ter se mudado para o distrito das Dores; ${ }^{25}$ AHRS - Eleições, EL-01. Evidentemente todos estes nove tipógrafos sabiam ler e escrever: (01) - Afonso Francisco da Silva Souto ( ${ }^{\circ}$ 656), 29 anos, solteiro, filho de Antônio Francisco da Silva Souto, morava na rua Senhor dos Passos $\left(27^{\circ}\right.$ Quarteirão), renda de 1:000\$; (02) - Elísio Antônio de Medeiros ( ${ }^{\circ}$ 1397), 26 anos, casado, filho de Fernando Antônio de Medeiros, morava no $4^{\circ}$ Distrito ( $9^{\circ}$ Quarteirão), renda de 300\$; (03) - Severiano Nunes Viana $\left(n^{\circ} 775\right), 63$ anos, solteiro, filho de Antônio Nunes Viana Misericórdia, morava no $2^{\circ}$ Distrito $\left(31^{\circ}\right.$ Quarteirão), renda de 300\$; (04) - Pedro Júlio Kopen ( $\left.{ }^{\circ} 858\right), 27$ anos, solteiro, filho de Pedro Júlio Kopen, residia na Voluntários da Pátria ( $2^{\circ}$ Distrito, $34^{\circ}$ Quarteirão), renda de 400\$; (05) - Joaquim Fortunato de Araújo $\left(\mathrm{n}^{\circ} 80\right), 34$ anos, solteiro, filho de Júlio Timóteo de Araújo, residia na rua do Vigário José Ignácio ( $\left({ }^{\circ}\right.$ Distrito ( $3^{\circ}$ Quarteirão), renda de 400\$; (06) - Melibo Correia de Araújo ( $\left.\mathrm{n}^{\circ} 364\right), 27$ anos, casado, ignorava-se a filiação, mora na Margem $\left(2^{\circ}\right.$ Distrito, $11^{\circ}$ Quarteirão), renda de $600 \$$; (07) - Carlos Augusto de Lima (n $\left.{ }^{\circ} 122\right), 33$ anos, casado, filho de José das Neves Lima, residia no $2^{\circ}$ Distrito ( $5^{\circ}$ Quarteirão), renda de 600\$; (08) - Antônio Gonçalves de Saibro Netto ( $\left.\mathrm{n}^{\circ} 716\right), 44$ anos, casado, ignorava-se a filiação, mora na Travessa 2 de Fevereiro ( $2^{\circ}$ Distrito, $30^{\circ}$ Quarteirão), renda de 600\$.; e (09) - Manoel Ignácio de Menezes (nº 187), 37 anos, solteiro, filho de Antônio Ignácio de Menezes, morava na rua Vigário José Ignácio ( $2^{\circ}$ Distrito, $7^{\circ}$ Quarteirão), renda de $800 \$$. 
Hypólito, mas construídas e mantidas por ele em suas atividades usuais. Ou seja, neste momento as redes construídas graças a seu pai foram reforçadas (ampliadas) por suas próprias relações.

Enquanto ganhava vida no mundo da tipografia, Aurélio promovia uma paralela e intensiva vida associativa. Às oito horas da noite de $1^{\circ}$ de junho de 1867, Aurélio foi proposto para sócio da Sociedade de Beneficência Porto-Alegrense, por iniciativa de João Firmo de Mello ${ }^{26}$. Aurélio completaria em outubro daquele ano 18 anos e segundo o livro de sócios desta associação o seu ingresso efetivo na mesma ocorreu em 10 de junho de 1867. A Sociedade de Beneficência Porto-Alegrense foi fundada em dezembro de 1856 e perdurou até 1936. Ela decorreu de uma cisão da primeira sociedade de socorros mútuos do Rio Grande do Sul, a Sociedade Portuguesa de Beneficência, fundada em Porto Alegre dois anos antes (Silva Júnior, 2008, p. 112 e 193).

No registro de sua associação, em 10 de junho de 1867, ele aparece como Aurélio Veríssimo [sic] da Conceição, natural desta Província, casado com Joana Joaquina de Bittencourt, empregado público, residente na rua do Arroio $\mathrm{n}^{\circ} 21$ (atual General Bento Martins), tendo atuado como secretário em 1868 e 1870 e vice presidente em 1871 . O termo de abertura deste livro é de 30 de novembro de 1871, o que justifica certas atualizações ou anacronismos, já que em 1867 Aurélio não era casado, nem havia ainda ingressado no serviço público provincial. Note-se que Aurélio não usa o sobrenome paterno - Bittencourt - e sim o da santa de sua devoção, o que indica que, mesmo que contasse com a ajuda de seu pai, não exteriorizava claramente a sua filiação, sendo reconhecido (e se reconhecendo) como filho natural ou bastardo ${ }^{27}$.

Dissidência da Sociedade Portuguesa de Beneficência, a Beneficência Porto-Alegrense sofreu por sua vez uma cisão. O motivo não é claro, mas em 25 de março de 1860, dia de eleições na associação, 33 sócios se retiraram e fundaram a Sociedade de Beneficência Brasileira União, que atuou

\footnotetext{
${ }^{26}$ Firmo foi um dos sócios fundadores desta associação. Em sessão de $1^{\circ}$ de outubro de 1867 ele comunicou sua ida para a Capital do Império e foi proposto um subsídio para a viagem "a vista de seu estado de indigência". A proposta foi aceita, sendo deliberado que ele receberia $40 \$$ se fosse só e $80 \$$ de fosse com a família.

${ }^{27}$ AHRS - Sociedade de Beneficência Porto-Alegrense, livro 30. Chama a atenção o sobrenome Conceição que, apesar de Aurélio ser devoto desta santa, não havia ainda aparecido em nenhum dos registros por nós pesquisados. Ele recebeu os santos óleos, em Jaguarão, amparado por seu padrinho Francisco José Vieira Valente e pela madrinha Maria Dorotéia do Nascimento, sendo introduzido na religião da qual nunca abdicaria, participando ao longo de sua vida de inúmeras irmandades. O pároco encomendado João Francisco Cabral Dinis, após batizá-lo solenemente, anotou em seu registro de batismo que Aurélio era filho de pais não conhecidos. Ao longo dos anos, entretanto, Aurélio invisibiliza sua madrinha Dorotéia e passa a citar Nossa Senhora da Conceição com sua madrinha espiritual.
} 
sob a proteção divina de São Sebastião ${ }^{28}$. Aurélio participou de ambas associações e inclusive esteve no cerne de uma discussão que tratou da reunificação da União com a Porto-Alegrense. Em abril de 1868 foi discutida a fusão das duas sociedades, mas levantou-se a objeção por parte da Porto-Alegrense de que a Sociedade União fazia restrição à participação de libertos nos seus cargos diretivos. Aurélio, expressando sua autorrepresentação como não branco e filho ilegítimo, retrucou que "se na Sociedade de Beneficência Brasileira União houvesse seleção de nascimento e de cores, ele orador não seria sócio dessa sociedade nem tampouco estaria ocupando o cargo de fiscal da mesma, e que não constando de documentos, nem sempre a voz pública é expressão da verdade"29.

Realmente, desde pelo menos setembro de 1867, Aurélio ocupava o cargo de Fiscal da Sociedade de Beneficência União. Essa sua inserção nesta associação, entretanto, não provava que a União aceitava incondicionalmente indivíduos egressos do cativeiro em seus cargos diretivos, já que Aurélio havia nascido livre. Nessa discussão, a palavra liberto parece ter uma conotação maior do que a corriqueira, de indivíduo egresso do cativeiro. A restrição aos libertos, se efetivamente aplicada, excluiria indivíduos negros nascidos livres, mas com ligações familiares com o mundo da escravidão. Ao defender a Sociedade de Beneficência Brasileira União dando como exemplo o seu caso pessoal, Aurélio amplia a noção de liberto para os negros em geral.

Através de ofício reservado datado de 30 de setembro de 1867 o Presidente da Província Francisco Inácio Marcondes Homem de Mello prestou informações ao Ministro da Justiça sobre as aulas noturnas criadas para os operários, pela Sociedade de Beneficência Brasileira União $^{30}$. Segundo Homem de Mello, a diretoria da União, do biênio 1867/1868, era assim composta:

\footnotetext{
${ }^{28} \mathrm{~A}$ escolha deste padroeiro teria sido motivada pela proteção divina a "pestes" (ver Silva Júnior, 2008, p. 91, 113 e 127). Segundo os seus estatutos a Sociedade de Beneficência Brasileira União tinha como fim especial: $\S 1^{\circ}$ Prover a subsistência dos sócios, ou suas famílias, que se acharem em estado de indigência; $\S 2^{\circ}$ Prover sobre o tratamento dos sócios enfermos no caso de, por qualquer eventualidade, não poderem trabalhar, e se acharem faltos de recursos; $\S 3^{\circ}$ Procurar ocupação para aqueles sócios que se acharem desempregados, isto quanto estiver no alcance da sociedade; $\S 4^{\circ}$ Concorrer para a educação e instrução dos filhos dos sócios pobres que o não poderem fazer; $\S 5^{\circ} \mathrm{A}$ disposição do $\S$ antecedente é extensiva aos filhos das viúvas, ainda que pensionadas pela sociedade, sendo arbitrada pela diretoria uma pensão para os menores em questão; $\S 6^{\circ}$ Proteger e defender perante os tribunais criminais todos os sócios que forem injustamente acusados, ou mesmo aqueles que compelidos por uma triste fatalidade tenham-se tornado réus, uma vez que a acusação não seja de ter praticado assassinato em juízo perfeito (quando não hajam circunstâncias que o justifiquem) furto, roubo e estupro. AHRS - Requerimentos, maço 98, diversos.

${ }^{29}$ Silva Junior, 2008, p. 251/252; AHRS - Sociedade de Beneficência Porto-Alegrense, Livro das Atas e mais Resoluções.

${ }^{30}$ ANRJ - Série Justiça - Gabinete do Ministro - maço IJ1856 (1866/69).
} 


\begin{tabular}{|c|c|c|}
\hline Presidente & Dr. José Antonio do Vale Caldre Fião & Médico \\
\hline Vice & Antonio José de Miranda Falcão ${ }^{\mathrm{a}}$ & \\
\hline $1^{\circ}$ Secretário & João da Fonseca Barandas Júnior & Empregado Públicob \\
\hline $2^{\circ}$ Secretário & José Luiz Teixeira Lima & Empregado Público ${ }^{c}$ \\
\hline Tesoureiro & Jeremias da Silva Moreira & Negociante $^{\mathrm{d}}$ \\
\hline Procurador & Manoel Dias Henriques & Idem \\
\hline Procurador & José Alves Leite de Oliveira Salgado & Empregado Público ${ }^{\mathrm{e}}$ \\
\hline Fiscais & Pedro Lopes Ribeiro & Operário $^{f}$ \\
\hline Fiscais & Antonio Correia Dias Moura Júnior & Empregado Público \\
\hline Fiscais & José Alves Coelho da Silva & Piloto da Armada ${ }^{\mathrm{g}}$ \\
\hline Fiscais & $2^{\circ}$ Tenente de Artilharia José Antonio Lessa & $\mathrm{h}$ \\
\hline Fiscais & Porfírio Pereira Gomes dos Santos & \\
\hline Fiscais & Aurélio Viríssimo de Bitencourt & \\
\hline
\end{tabular}

a Falcão, entre julho de 1865 e abril de 1866, foi oficial da Secretaria de Governo Provincial, sendo depois distribuidor, contador e partidor do foro da Capital. AHRS - Requerimento, maço 142 (Justiça); Fazenda - códices F-262 e F-334.

${ }^{\text {b }} \mathrm{Na}$ lista de votantes da paróquia do Rosário, de 1880, consta ter 50 anos, casado, professor, filho de João da Fonseca Barandas, morador na rua Senhor dos Passos e ter de renda 1:800\$.

c José Luiz Teixeira Lima foi nomeado Amanuense da Estatística provincial por provisão de 12.09.1848, ficando até o ano seguinte. Por ordem do Presidente da Província foi encarregado dos merinos do asilo de Santa Teresa. Entre 1857 (provisão de 20.06) e 1861 atuou como colaborador da Estatística. Entre 22 de julho de 1861 e 25 de julho de 1864 serviu como amanuense na repartição da estatística, até a extinção da mesma. Entre setembro de 1864 e agosto do ano seguinte foi o encarregado da guarda dos papéis, mapas e instrumentos que pertenciam a Repartição da Estatística e Arquivo das Obras Públicas, até ser exonerado a ser pedido em 02.08.1865. Serviu ainda como $3^{\circ}$ Oficial da Diretoria Geral da Fazenda Provincial até ser aposentado por ato e título de 29.01.1881. Faleceu em 26.12.1886. Em 21.04.1864, quando era amanuense da estatística, pediu um mês de licença e serviu como quartel-mestre no $4^{\circ}$ corpo de Guardas Nacionais de Missões e depois no $4^{\circ}$ corpo de Cavalaria de São Leopoldo. AHRS - Fazenda, códices F-261, F-262, F-306, F-312, F-318, F-323 a F-332; Requerimentos, maço 109. Teixeira Lima, enquanto funcionário da estatística provincial, foi autor do Relatório sobre plantas e drogas medicinais, com a indicação do município onde podem ser encontradas (Witter, 2007, p. 169).

d Em 1874 o negociante Jeremias da Silva Moreira foi processado pelo comerciante José Fernandes Granja, por causa de uma dívida de quinhentos mil réis, feita em 1871. Mediante um auto de penhora e depósito executado por dois oficiais de justiça, vários bens (aguardente, vinho, erva, etc.) foram apreendidos na casa de negócio ou taberna localizada na rua General Lima e Silva, outrora da Olaria, canto do Beco do Oitavo. Logo em seguida, Antonio José Vieira Guimarães reclamou ser o verdadeiro dono da taberna, provando que pagava $32 \$$ réis de aluguel pela casa a Joaquim Tomás de Cantuária, além dos impostos respectivos (aferição de balança, indústria e profissões) para a Câmara Municipal. Guimarães então esclareceu que Jeremias era o seu caixeiro e cunhado, alegação aceita pelo juiz. APERS - Juizo de Direito do Comércio, auto 2977, maço 99, Executor: José Fernandes Granja, Executado: Jeremias da Silva Moreira; APERS - Juiz de Direito da $1^{\text {a }}$ Vara do Comércio, auto 5406, maço 147, Autor: José Fernandes Granja, Réu: Jeremias da Silva Moreira. 1874.

- A única informação que obtivemos de José Alves Leite de Oliveira Salgado é anterior a sua participação na Sociedade União: em 1863 era Coadjuvador da Escrituração do Arsenal de Guerra. AHRS - Requerimentos, maço 105.

${ }^{\mathrm{f}}$ Segundo a lista de votantes qualificados na paróquia do Rosário, de 1880, Pedro Lopes Ribeiro tinha 59 anos, era casado, proprietário, sabia ler e escrever, ignorava-se sua filiação e tinha uma renda de 2:000\$. Pedro era católico, português (naturalizado brasileiro), filho legítimo dos finados Pedro Lopes Ribeiro e Tereza Maria de Jesus, casado na Igreja com Suzana Marcolina Lopes, sem filhos. Suzana era natural desta Província, filha legítima dos também finados Fabiano Bueno da Silva e Leocádia Maria da Silva. Pedro e Suzana confeccionaram o testamento juntos, em 31.05.1881, "de saúde e em nosso perfeito juizo e claro entendimento", sendo ela a primeira a falecer, em 07.11.1881. O caráter de proprietário de Ribeiro fica evidente em uma ação de 1893, em que pede o pagamento de aluguéis atrasados, devidos por seu inquilino Gaspar Fernandes dos Reis, que alugara a casa $\mathrm{n}^{\circ} 8$ da rua dos Andradas (16\$ mensais). No recibo de pagamento da décima urbana anexo, de 04.01.1893, consta que Ribeiro tinha 4 imóveis. Além do da Andradas $n^{\circ} 8$, tinha na mesma rua o $\mathrm{n}^{\circ} 6$ e na Riachuelo os prédios 29 e 22. APERS - Cartório da Provedoria, 1881, POA, auto 2088, maço 70, testador: Suzana Marcolina Lopes, Testamenteiro: Pedro Lopes Ribeiro.

g A informação que temos de José Alves Coelho da Silva remonta muitos anos após sua participação na Sociedade União. Em 1887 era $1^{\circ}$ tenente reformado da Armada e residia em Rio Grande. Em abril de 1888 era professor público e regia a escola de $1^{\circ}$ grau da Cachoeira. AHRS - Requerimentos, maço 260 (Instrução Pública) e maço 263.

${ }^{\text {h }}$ Lessa em 1868 moveu uma ação por injúrias contra o proprietário do Jornal do Comércio Luiz Francisco Cavalcante Albuquerque. $\mathrm{O} 2^{\circ}$ Tenente reformado do Exército José Antonio Lessa era natural do Rio de Janeiro e morava em Porto Alegre, onde vivia do "soldo e dos réditos do jornal Inflexivel, que possui". APERS - $1^{\circ}$ Cartório Cível e Crime de Porto Alegre, maço 133, processo 3584. O $2^{\circ}$ Tenente Lessa era casado com Hortência Adelaide Gama Lessa, falecida em 1865 , e genro de Fausta Cândida Bivar da Gama e do Capitão José Maria de Almeida Gama Lobo d'Eça. Os bens do casal, quando do falecimento de Hortência, montavam a 830 mil réis: a crioula Inês, de 30 anos (800\$), jóias (20\$) e dois baús cobertos de couro (10\$). A herança era devedora de José Antonio Portela, por uma dívida para o funeral, médico e botica. APERS - Juízo de Órfãos, Auto de notificação para inventário, auto 3240, maço 136; APERS - $2^{\circ}$ Cartório de Órfãos POA, 1865, auto 311, maço 18 . 
A diretoria acima, segundo o Presidente da Província, era responsável pelo "projeto e fundação do Hospício, cuja pedra fundamental se deve lançar no dia 15 de outubro futuro, a criação do Dispensatório Homeopático, do qual é diretor o Dr. Caldre Fião, e que já tem tratado de 13 de maio até 9 deste mês 436 doentes pobres, e o complemento do Instituto para os operários, em cujas aulas noturnas os operários recebem o ensino profissional". Os professores deste instituto, que lecionavam gratuitamente, ministravam as seguintes matérias: geometria (com 20 alunos), desenho (com 8), química, física e mecânica (com 10) e francês (16 alunos). O pessoal do Instituto para os operários era o seguinte:

\begin{tabular}{|l|l|}
\hline Preparatórios \\
\hline Francês e aritmética & Professor Bibiano Francisco de Almeida $^{\mathrm{a}}$ \\
\hline Inglês & Professor Júlio Timóteo de Araújo \\
\hline Alemão & Está acéfalo \\
\hline História e geografia & Professor Apolinário Porto Alegre \\
\hline Ensino profissional & \multicolumn{2}{|l|}{} \\
\hline Geometria prática e desenho linear & Professor João Propício Rodrigues da Silva ${ }^{\mathrm{c}}$ \\
\hline Mecânica, física e química & Professor Dr. Antonio Eleutério de Camargo \\
\hline Arquitetura & Professor Dr. Antonio Teles de Freitas Mascarenhas \\
\hline
\end{tabular}

a Em 9 de julho de 1868 foi esfaqueado em frente ao edifício do Arsenal de Guerra, no centro de Porto Alegre, o marítimo português Jacinto José de Oliveira pelo escravo angolano Mateus. O professor Bibiano Francisco de Almeida estava em um iate na rampa do Arsenal e testemunhou tudo. Tinha então 31 anos, era casado, natural desta província. APERS - Porto Alegre - Sumários - Júri, Maço 40, processo 1175. Em 26.02.1872 Bibiano, alegando ser "professor de latim dos principais colégios desta capital", solicitou e foi nomeado interinamente para professor do Ateneu Rio-Grandense. AHRS - Requerimentos, maço 158. Em 1862 o professor Bibiano Francisco de Almeida foi chamado a uma audiência de conciliação, decorrente de uma dívida de 700 mil réis que desde 1859 tinha com Manoel Joaquim de Carvalho e Souza. A interpelação judiciária não foi feita por Souza, mas por João Marcelino Pires, que era o fiador de Bibiano nesse empréstimo e enquanto tal teve que saldar a obrigação pecuniária. Bibiano era, então, casado com Maria Luiza de Almeida e morava em uma casa rua da Varzinha. APERS - Juízo de Paz do Distrito das Dores, Porto Alegre, 1862, Auto n 31 , Processo judicial / conciliação, Suplicante: João Marcelino Pires, Suplicado: Bibiano Francisco de Almeida.

b Júlio Timóteo de Araújo foi adido das Obras Públicas entre janeiro e dezembro de 1870 e professor de Inglês do Extinto Liceu. Foi aposentado por Ato de 07.01.1873. AHRS - F-338, F-339, F-298. Ele era filho de José Joaquim Timóteo de Araújo e Feliciana Maria Liberata de Araújo) e casado com Joaquina Calderon de Araújo (filha de José e Josefa Calderón), e ambos faleceram em 1874, com poucos meses de distância um do outro, deixando quatro filhos: Joaquim Fortunato de Araújo (solteiro, maior idade), Justino Cesar de Araújo (17 anos), Carlota Amália de Araújo (16 anos) e Sara Adelina de Araújo (12 anos). O primogênito Joaquim foi o inventariante e não é a primeira vez que ele aparece nesse artigo, constando na Lista de Votantes da Paróquia do Rosário, de 1880, como tipógrafo. APERS - $1^{\circ}$ Cartório de Órfãos - Inventário, auto 2093, maço 100, Inventariado: Julio Timotheo de Araújo e Joaquina Calderon de Araújo, Inventariante: Joaquim Fortunato de Araújo, 01/01/1875. O cadete João Propício Rodrigues da Silva teve título de agrimensor registrado na província desde 1857 . Entre 1856 e 1861 foi Praticante de Desenho Extraordinário para serviço do arquivo provincial. Por título de 11.06.1866 foi nomeado Professor de Geometria, Mecânica e Desenho com aplicação às Artes do Arsenal de Guerra, onde permaneceu até 1870. Por provisão de 16.01.1871 foi empossado como Condutor (Obras Públicas), onde ficou até 1889. AHRS - F-220 a 223, F-228 a 246, F-334 a F-339; Requerimentos - maço 112. Ele faleceu em 08.11.1894, em Porto Alegre, deixando a viúva Márcia Ferreira da Silva e 4 filhos: Otávio Rodrigues da Silva, Vitória Rodrigues Xavier, Propício Rodrigues da Silva e Conisa Rodrigues da Silva. O casal possuía um único bem, uma casa na rua Cel. Fernando Machado, $\mathrm{n}^{\circ} 108$, com uma porta e duas janelas, avaliada em seis contos de réis (APERS - $2^{\circ}$ Juízo de Órfãos - Porto Alegre, 1895, Inventário, Auto 822, Inventariado: João Propicio Rodrigues da Silva, Inventariante: Marcia Ferreira da Silva, Data do processo: 01.01.1895).

${ }^{d}$ Por título de 14.02.1867 Camargo foi nomeado Engenheiro Ajudante das Obras Públicas, sendo demitido por ofício do secretário de 12.09.1868; em 1871 era Engenheiro Chefe do $2^{\circ}$ Distrito, sendo concedida sua exoneração em 04.08.1871 (AHRS - Fazenda, códices F-228, F-335 a F-337).

e Antônio Mascarenhas Telles de Freitas atuou como coadjuvador Ajudante do Diretor do Arquivo Provincial desde a sua provisão de 06.03.1862 até o fechamento deste arquivo em 01.07.1864. Entre 1864 e 1865 foi fiscal da obra da muralha da cadeia civil de Porto Alegre. Entre fevereiro de 1867 e 1871 foi Engenheiro Ajudante das Obras Públicas provinciais, sendo nomeado Diretor Chefe do $4^{\circ}$ Distrito por provisão de 15.07.1871. Em 10.05 do ano seguinte foi nomeado Diretor da Repartição de Obras Públicas e Chefe da $1^{\circ}$ Seção. Entre 1872 (22.11) e 1873 foi Engenheiro Fiscal das Companhias de Gás e Bondes e entre 20.10.1874 e 1877 foi Engenheiro Ajudante do Diretor das Obras Públicas (AHRS - Fazenda, códices F-224 a 234, F-261, F-335 a 337). 
Talvez alguns destes indivíduos Aurélio conhecesse de suas iniciativas ligadas ao associativismo devocional (das irmandades) - que não abordaremos neste artigo. Entretanto, pelos dados que cotejamos de fontes diversas, percebemos que entre as características comuns deste pequeno e seleto grupo, está o contato com a esfera pública, principalmente em sua instância provincial. Compartilhar redes sociais, profissionais e políticas como esta deve ter facilitado seu passo profissional seguinte, ao ingressar no serviço público provincial.

O Presidente da Província de São Pedro do Rio Grande do Sul, naquele delicado período bélico, já foi citado neste artigo outras vezes - era o Barão Homem de Mello, que em 1903 pediu a gentileza de que seu prezado amigo Aurélio Viríssimo de Bittencourt fosse se inteirar do estado de saúde do General Xavier do Vale. Se nos reportarmos ao relatório feito por Homem de Mello à Assembleia Provincial, em 4 de setembro de 1867 , e ao que entregou a presidência ao $1^{\circ}$ VicePresidente, o Dr. Joaquim Vieira da Cunha, em 13 de abril de 1868, verificaremos que ele, apesar da Guerra do Paraguai, demonstrou muita atividade.

Homem de Mello, em sua passagem pelo governo provincial, reestruturou a Secretaria de Governo, estipulando um novo regulamento, em 13 de janeiro de 1868, o qual estava anexo ao Relatório do mesmo ano. ${ }^{31}$ Dividia-se a Secretaria do Governo (ou da Presidência) em 4 seções, administrada, além do secretário, por um oficial-maior, 4 chefes de seção, 6 primeiros oficiais, 6 segundos oficiais, 4 amanuenses, 1 porteiro, 1 contínuo e dois correios. Ao contrário dos demais funcionários, que eram da livre nomeação do Presidente da Província, os segundos oficiais e os amanuenses deveriam prestar exame.

Os amanuenses deveriam obrigatoriamente ter "boa letra, conhecimento da gramática portuguesa e da língua francesa, da aritmética até proporções e de geografia pátria e corografia da Província" (artigo $5^{\circ}$ ). Os empregados da secretaria deveriam ter a maioridade legal, com exceção dos amanuenses, que poderiam "ser nomeados com 18 anos completos de idade, tendo as necessárias habilitações". O concurso para preenchimento dos dados deveria ser divulgado pela imprensa com 30 dias de antecedência e as pessoas de fora da repartição que quisessem pleitear alguma vaga:

${ }^{31}$ AHRS - Relatório com que Francisco Inácio Marcondes Homem de Melo passou a administração para o $1^{\circ}$ Vice-Presidente Joaquim Vieira da Cunha, em 13 de abril de 1868. 
[...] deverão dirigir à presidência suas petições, acompanhadas de certidão de idade, folha corrida e quaisquer outros documentos que possam exibir em abono de seu procedimento e capacidade, e obtendo despacho que os admita a concurso, serão obrigados a trabalhar gratuitamente na secretaria por espaço de 8 dias. [artigo 11]

O exame de cada pretendente duraria no mínimo uma hora, seria coordenado pelo Presidente da Província e realizado por dois examinadores por ele nomeados e pelo secretário de governo, os três tendo direito a voto. $\mathrm{O}$ voto dos examinadores era secreto e cada um deles deveria fazer um parecer, "classificando os concorrentes, conforme o seu merecimento". Competia aos amanuenses e aos $1^{\circ} \mathrm{s}$ e $2^{\circ} \mathrm{s}$ oficiais, "cumprir com zelo e prontidão as ordens relativas ao serviço público, que receberem dos seus chefes de seção, oficial maior ou secretário" (artigo 42).

Os trabalhos da secretaria seriam desempenhados todos os dias úteis, das 9 às 15 horas, com a ressalva de que "serão chamados os empregados para o expediente ordenado pelo Presidente da Província, a qualquer hora do dia ou da noite, compreendidos os dias de guarda e feriados", ficando sujeitos todos os funcionários (com exceção do secretário e do oficial maior) ao ponto (artigos 23, 24 e 25).

Em 11.02.1868, necessitando disto para candidatar-se ao emprego público, Aurélio pediu ao Delegado de Polícia que lhe providenciasse "folha corrida com as culpas do suplicante, ou sem elas". Em 15 do mesmo mês requereu ao Presidente da Província Homem de Mello sua aceitação ao concurso de amanuense(IHGRS - APAVB - Pasta 4).

$\mathrm{O}$ exame a que se submeteu Aurélio deve ter sido, segundo mandava o regimento, supervisionado diretamente pelo Presidente da Província Homem de Mello e pelo então Secretário de Governo, o Bacharel João José do Monte Júnior. ${ }^{32}$ Não sabemos quem foram os examinadores, mas quatro vagas foram providas naquele ano, uma de $1^{\circ}$ oficial (Antonio da Fontoura Barreto), e três de amanuenses (Pedro Garceau Pereira Coelho, Felix Ferreira de Mattos Júnior e Aurélio Viríssimo de Bittencourt). Todos foram efetivados por Provisão provincial de 6 de abril de $1868 .{ }^{33}$

\footnotetext{
${ }^{32}$ Secretário entre 1866 e 1868 . AHRS - F-335, F-336

${ }^{33}$ Os quatro fizeram carreira no funcionalismo público, no qual ingressaram naquele exame de 1868: Antônio da Fontoura Barreto ( $2^{\circ}$ Oficial entre $1868 / 1878,1^{\circ}$ Oficial entre 1878/81, Oficial de Gabinete entre 1881/1884, Diretor da $4^{a}$ Seção nomeado em 19.02.1881 e Diretor Geral por ato de 14.11.1884), Pedro Garceau Pereira Coelho (Amanuense de 1868 a 71, $2^{\circ}$ Oficial de 1871/80, $1^{\circ}$ Oficial de 1881/88), Felix Ferreira de Mattos Júnior (já aparece como Colaborador nas Obras Públicas provinciais, empregado no registro da correspondência oficial em 1867/1868, amanuense de 1868 a $1869,2^{\circ}$ Oficial de 1869/76, Oficial de Gabinete de 1876/77, $1^{\circ}$ Oficial de 1877/84 e Diretor da $4^{\text {a }}$ Seção entre 1884/88) (AHRS - Fazenda F-335/355).
} 
Não sabemos se este foi o primeiro encontro do pardo Aurélio, com seus 19 anos, e o futuro Barão Homem de Mello, mas supomos que o seu acesso a burocracia provincial se deu pela soma de seu próprio capital relacional já acumulado, pelo patrimônio material e imaterial de seu pai e por seu talento e capacidade pessoal.

Mas aquele ano de 1868 foi especial, pois outros vértices relacionais podem ser localizados, unindo estes indivíduos e suas trajetórias pessoais. Tratando das comandâncias militares da fronteira sulina, Homem de Mello, em seu relatório de 13 de abril de 1868, comunica várias mudanças nos postos, entre elas a nomeação do Capitão do Estado Maior de $2^{\text {a }}$ Classe e Major da Guarda Nacional Joaquim Antonio Xavier do Vale, por Aviso de 23.11.1867, para comandante da guarnição da cidade de Jaguarão, substituindo o Major do Estado Maior de $1^{\text {a }}$ Classe Francisco Rafael de Melo Rego, que assumiu o mesmo posto em Pelotas. ${ }^{34}$ Aliás, em 5 de agosto de 1865, quando da invasão paraguaia da vila de Uruguaiana, essa localidade contava para sua defesa com 380 homens comandados pelo Capitão Joaquim Antonio Xavier do Vale (AHEx - Pasta IV-21-40).

$\mathrm{O}$ estado de constante beligerância da fronteira sulina fez com que se acumulassem tropas em suas linhas e que passagens pela Província do Rio Grande do Sul aparecessem reiteradamente nos currículos (ou fés-de-ofício) militares. Em 1851 o Alferes Xavier do Vale expedicionou com o $2^{\circ}$ Batalhão de Infantaria ao Estado Oriental do Uruguai, sendo a primeira vez que visitava a província meridional. A militarização da província abria boas (embora às vezes arriscadas) oportunidades de progressão na carreira castrense (Ribeiro, 2009). Em 1863, como Capitão, assumiu o comando da guarnição da cidade de Cachoeira, passando no mesmo ano para igual posto em Uruguaiana. Lá estava quando o Exército Paraguaio invadiu a Província, em 11.06.1865. Seguiu com o Exército Aliado para o Estado Oriental e dele retirouse a 15.04.1867. Em 21.01.1868 assumiu o comando da guarnição de Jaguarão e de lá, novamente, marchou como secretário do $1^{\circ}$ Corpo do Exército em Operações no Paraguai, em 07.06.1869, retirando-se para Brasil em 23.11 do mesmo ano. Naquele ano assumiu o comando da guarnição de Rio Grande e recebeu promoção para Major (em 30.10.1869, por atos de bravura). Em 1871 era secretário do Inspetor dos corpos do Rio Grande do Sul. Através do Decreto de 06.9.1870 e ${ }^{34}$ AHRS - Relatório com que Francisco Inácio Marcondes Homem de Melo passou a administração
para o $1^{\circ}$ Vice-Presidente Joaquim Vieira da Cunha, em 13 de abril de 1868, A.7.09: p. 4 . 
Diploma de 14.01.1871, foi condecorado como Oficial da Ordem da Rosa por serviços prestados na Guerra do Paraguai, nos combates de dezembro de 1868 e das Cordilheiras. Em 1872 era diretor interino do Laboratório Pirotécnico em POA e em 1874, secretário da Escola Militar do RGS. Em 1880 acompanhou o então Ministro da Guerra, Tenente general Visconde de Pelotas, até a Corte, a cujas ordens se achava. De volta ao sul, reassumiu no ano seguinte como secretário da Escola Militar e no mesmo ano tomou posse como diretor do Laboratório Pirotécnico, onde ficou até 1889. Desde 03.11.1883 era Tenente Coronel graduado e em 18887 recebeu a Ordem do Mérito Militar.

Em 1869, exatamente no dia da Imaculada Conceição (8 de dezembro), Aurélio Viríssimo de Bittencourt pagou quatro mil réis de joia e foi aceito com irmão da Irmandade de Nossa Senhora da Conceição de Porto Alegre, obrigando-se "a pagar anualmente 640 réis" 35 . Em 1871, quando passou a ocupar-se como secretário do Inspetor dos corpos militares do Rio Grande do Sul, instalando-se com sua família na capital provincial, o Major Xavier do Vale também tratou de preparar-se para uma boa morte e filiou-se a mesma irmandade, na qual também ingressou seu filho menor Antonio, no ano seguinte ${ }^{36}$.

É difícil para os historiadores saber como as relações se estabelecem e se efetivam as solidariedades e cumplicidades. Em muitos casos o que temos são pistas que indicam o cruzamento das existências individuais e familiares e assim supomos o estabelecimento de conexões. Mas nesse caso pelo menos, graças a excepcionalidade das fontes existentes sobre Aurélio Viríssimo de Bittencourt, podemos comprovar a persistência dos laços ai circunstancialmente forjados. Claro que não sabemos se foram forjados nesse momento ou se eram anteriores a 1868, mas com certeza persistiram por décadas.

Ainda tomando como observatório esta passagem do futuro Barão Homem de Mello pela presidência desta Província do extremo-sul do Império, conseguimos localizar mais enredamentos relacionais, geradores de afinidades e auxílios mútuos.

Através do Aviso Circular do Ministério da Agricultura, Comércio e Obras Públicas, de 7 de abril de 1867, foram solicitadas aos Presidentes das Províncias, informações sobre a "navegação presente e futura dos rios, lagos e baias desta Província e dos seus usos". O ágil Homem de

\footnotetext{
${ }^{35}$ AHCMPA - Termos de Entrada de Irmãos - 1845/1898, folha 35v. Em 1872 e 1880 Aurélio aparece como escrivão desta Irmandade.

${ }^{36}$ AHCMPA - Termos de Entrada de Irmãos da irmandade de Nossa Senhora da Conceição, folha 41v, 26-4-1871, e 52v, 7-4-1872.
} 
Mello, certamente com o auxílio dos funcionários provinciais, tratou diligentemente do assunto e por isso encontramos, anexo ao texto de sua exposição da situação provincial, o "Relatório sobre a abertura do sangradouro da Lagoa Mirim, do Engenheiro Ajudante da Repartição de Obras Públicas, Antonio Mascarenhas Telles e Freitas". Nesse interessante documento, anexo ao relatório de 1867, Telles e Freitas historia que os últimos trabalhos a respeito datavam de 1853, quando da administração de Oliveira Bello, quando foi nomeado o Capitão de Mar e Guerra Diogo Inácio Tavares, o qual, com um oficial de marinha e dois práticos, estabeleceu o melhor local e iniciou a desobstrução, cujos trabalhos adentraram a administração Sinimbu. O canal escavado, apesar de alguns problemas, garantiu a navegação na lagoa Mirim por 10 anos, "lagoa para nós importante, por ser a melhor via de comunicação que temos para as fronteiras do Chui e Jaguarão e cidade deste nome". Telles e Freitas advogava a importância da retomada os trabalhos de desobstrução e estimava que poderia ser realizado pela módica quantia de 233:838\$440 (em 3 anos).

Homem de Mello informa que, ao chegar à Província, encontrou a esquadrilha da Lagoa dos Patos composta dos vapores Amélia, Apa, Fluminense e Cachoeira. O primeiro deles tinha o casco de madeira em muito mau estado, não se prestando para "condução de tropas e carga de peso". O Presidente recomendou ao governo imperial que este vapor fosse desarmado e passasse a "rebocar os batelóes da barca de escavação", economizando assim o governo cerca de 1:200\$. Para substituir o Amélia, foi comprado o vapor Mauá, que estava sob consertos na Corte, vindo para a Província e sendo rebatizado de Silveira.

Correndo o risco de afogar em nomes os talvez já atônitos leitores, inseriremos mais um indivíduo nesta narrativa. Em 14 de março de 1823 nascia em São Miguel, Província de Santa Catarina, Hypólito Simas de Bittencourt, filho legítimo de Antonio José Guerra e Damásia Caetana de Simas. Oriundo de gente humilde, ainda menino transferiu-se, com seus pais, para a cidade de Rio Grande. Com 18 anos, Hypólito foi nomeado, em 11 de maio de 1841, para servir de Piloto a bordo do vapor "Fluminense". Dali, foi uma sequência de escunas e vapores, até que, em 20 de outubro de 1847, Hypólito passa a tomar conta da "escrituração de Fazenda" da canhoneira Jaguarão, que seria desarmada. Ele já havia exercido as funções de escrivão do cuter Guarany em 1842 e certamente estava habilitado para esta tarefa. Talvez por esta época, tendo de permanecer mais tempo em Jaguarão, ele adquiriu um terreno 
(do qual tinha título) de 120 palmos de frente com 1 quadra de fundos na rua das Flores ${ }^{37}$.

O certo é que estes trabalhos de melhorias de trânsito marítimo na Lagoa Mirim é que levaram o piloto da Marinha Hypólito para a fronteira do Jaguarão. Segundo relatou o Presidente da Província Cansansão de Sinimbu, em seu relatório de 1855:

\section{SANGRADOURO DA LAGOA MERIM NO RIO SÃO GONÇALO.}

Está realizado um dos maiores benefícios a que tinha direito o importante comércio da fronteira de Jaguarão e a navegação da Lagoa Mirim, com a franca abertura do Sangradouro da mesma Lagoa no rio São Gonçalo. Esta obra, em que se despendeu a soma de 26:701\$184 réis, compreendidos os multiplicados reparos que foi mister fazer na barca de escavação, tanto no decurso do trabalho como para pô-la em estado de ser restituída à Associação Comercial, tendo sido interrompida no inverno do ano passado recomeçou em Setembro e finalizou no dia 9 de Março do corrente ano. Assim se exprime acerca dela o piloto da Barca Amelia Hypolito de Simas Bitencourt, encarregado desse trabalho, e que no desempenho dele deu provas de inteligência e muito zelo. "O canal aberto contém 810 braças de extensão e 12 de largura, regulando em todo ele 11 palmos de profundidade no estado médio das águas. Ele ficou igualmente balizado em toda sua extensão". Será para desejar que o movimento das águas não o obstrua novamente..$^{38}$ [grifos nossos]

Segundo o general e historiador Antonio da Rocha Almeida, "por essa época, Hypólito fico certo de que encontrara, nos encantos de uma moça jaguarense, o conforto e o carinho de que necessitava nos curtos interregnos dos longos cruzeiros a que o obrigava a vida do mar". $\mathrm{Na}$ fronteiriça Jaguarão o marinheiro Hypólito se enamorou de Maria Júlia da Silva (que morava com sua mãe Josefa) "e pelo Natal de 1848 uniram seus destinos" (Almeida, 1962).

Uniram seus destinos soa como uma tímida metáfora para que não se diga claramente que aquela relação não foi consagrada na Igreja. Consagrou-se um amasiamento, do qual frutificou o nosso personagem

\footnotetext{
${ }^{37}$ AHRS - Autoridades Municipais - Caixa 36, Maço 80, ofício dos vereadores de Jaguarão ao Presidente da Província, em 11 de outubro de 1848. A rua Dr. Flores também se chamou rua das Fontes, rua do Imperador e, após a proclamação da república, Mal. Deodoro.

${ }^{38}$ AHRS - Relatório com que o Dr. João Lins Vieira Cansansão de Sinimbu entregou a presidência da Província de S. Pedro do Rio Grande do Sul ao vice-presidente Dr. Luiz Alves Leite de Oliveira Bello, no dia 30 de junho de 1855. Porto Alegre, Tipografia do Mercantil, 1855.
} 
principal, Aurélio. Hypólito deve ter desembarcado no porto de Jaguarão a bordo do vapor Amélia (citado no relatório acima), embarcação armada com um canhão, incorporada a marinha em 1840 e que em 1867 foi desarmada, dando baixa do serviço ativo. Hypólito abandonou o vapor Amélia e a Província sulina em 22.09.1857, quando foi mandado para a Corte prestar exames e, logo em seguida, para a Província do Mato Grosso $^{39}$. Sua transferência coincidiu com a promoção para segundo tenente em 09.01.1858. Naquela Província Hypólito ficou por vários anos e foi onde deu a conhecer ao Império sua bravura em um ato heroico de resistência aos invasores paraguaios. Sua fé-de-ofício assim relata o ocorrido:

Em 07.07.1864 apresentou-se a bordo do vapor Anhambahy, a cuja guarnição ficou pertencendo. Por ordem do Comandante da Flotilha de Mato Grosso assumiu o comando interino desse vapor em 02.09 seguinte. Por doente passou para o vapor Jaurú em 27.12 do mesmo ano, afim de recolher-se ao Hospital de Cuiabá; em viagem, porém, piorou de tal maneira, que necessário foi desembarca-lo no porto denominado Três Barras, fazenda de João Dias, na margem do rio Paraguay. Invadindo os paraguaios essa fazenda foi forçado a internar-se pelas matas para salvar a vida e, por isso, só pode apresentar-se, ainda doente, a bordo do vapor Jaurú em Melgaço, em 28.03.1865 e nele seguindo para Cuiabá, baixou ao hospital em 17.04 seguinte.

Hypólito esperou alguns anos para ser recompensado por tal intrepidez, mas por decreto de 09.04.1871 foi nomeado cavaleiro da Ordem de São Bento de Avis, recebendo não só um vistoso diploma, mas uma venera de ouro, cravejada de brilhantes, entregue, segundo parece, pessoalmente pelo Imperador. Pois essa condecoração, carregada de dons simbólicos e não pouco valor material, foi um dos motivos da briga de Aurélio e sua tia Leocádia durante o inventário dos bens de Hypólito, em 1884.

Mas como os tempos eram belicosos, Hypólito nem teve tempo de se recuperar física e emocionalmente e já foi removido para o serviço ativo da armada na flotilha do Rio Grande do Sul, retornando ao vapor Amélia em 31.10.1865. Em 15.04.1867, já com o Barão Homem de Mello na presidência na Província, Hypólito continuou sua itinerância,

${ }^{39} \mathrm{AMRJ}-3^{\circ}$ Livro Mestre dos oficiais da Armada Nacional Imperial, folhas 223-4; APAVB - Pasta 2 - Estado e Anexos. 
passando para o vapor Silveira, em 15.04.1867 e depois para o comando do vapor Cachoeira. Portanto, naqueles marciais anos de 1867 e 1868, o vértice verificado em 1903 estava montado: o Capitão Joaquim Antonio Xavier do Vale no comando da guarnição da cidade de Jaguarão, o Segundo Tenente da Armada Hypólito Simas de Bittencourt navegando pelas vias fluviais sulinas e o futuro Barão Homem de Mello na presidência da Província. Se não podemos provar que se conheciam pessoalmente, dificilmente se ignoravam e é provável que tenham trocado correspondências, pelo menos oficiais ${ }^{40}$.

Assim, enquanto o pai comandava vapores da flotilha sulina, após destemidamente ter fugido (ou recuado) do avanço das tropas agressoras paraguaias, o jovem Aurélio fazia concurso e era admitido no funcionalismo público provincial. Sabemos que várias sendas se abrem e se fecham nas experiências de vida à medida que transcorrem os anos, algumas transcorremos apenas um trecho, em outras não ingressamos e noutras seguimos adiante por longos anos. Sabemos que essas escolhas não são absolutamente livres, principalmente em uma cultura relacional, como a que permeava a sociedade dos oitocentos. Destinos trilhados por familiares eram patrimônios que condicionavam e influenciavam as decisões quanto as trilhas ou carreiras a seguir. Então, nossa indagação momentânea foi: que motivos afastaram Aurélio da carreira na armada imperial? Sem nos alongarmos muito na questão, a historiografia que nos últimos anos se dedicou a uma Nova História Militar, apesar de tratar mais enfaticamente dos estratos mais baixos das forças armadas imperiais (recrutamentos de soldados e marinheiros, por exemplo), tem evidenciado que a carreira do oficialato da armada era dificilmente trilhada por indivíduos não brancos ${ }^{41}$. Assim, o pardinho Aurélio migrou da fronteira sul para a capital da Província em busca de outras fortunas.

Lembrando que a mobilidade social que estamos acompanhando não é só de Aurélio, mas de seu pai, egresso de uma humilde família, assim, trata-se, de certa forma, de uma lógica familiar, que se percebe na sua saída de Jaguarão, acompanhando o pai e deixando a mãe e, em 1868, ingressando como amanuense no corpo de funcionários provinciais.

\footnotetext{
${ }^{40}$ Outro dado, daqueles que podem ser reveladores, é que no registro do batismo de um dos filhos do então Major Xavier do Vale, Antonio, batizado em 20.03.1871 na Igreja das Dores, em Porto Alegre, consta que seu pai era natural da Província do Mato Grosso e sua mãe do Rio de Janeiro. Não tivemos acesso, ainda, a fé-de-ofício desse militar, assim não sabemos se os destinos dele e de Hipólito não se cruzaram já naquela província (AHCMPA - Livro 3 de Batismos de Livres das Dores, folha $67 \mathrm{v})$.

${ }^{41}$ Ver: Arias Neto, 2001; CASTRO, (e outros; org,), 2004; JEHA, 2011; Nascimento, 2001. Agradecemos ao historiador Vinicius Oliveira pelas informações sobre esta questão.
} 
O parágrafo acima encerra uma das interfaces que se destacam em nossa investigação - a inserção de negros na burocracia Imperial e, após, republicana. Pensamos que o ingresso no funcionalismo público foi uma alternativa recorrentemente usada pelos indivíduos negros - portadores de certo capital cultural e social acumulado - como estratégia de mobilidade social. (Grinberg, 2002) A burocracia - se é que podemos usar este termo para o período -, ao longo do Império foi vítima das necessidades dos governantes saciarem as pretensões de cargos das elites provinciais. A Coroa Imperial encontrava-se em uma dúbia e precária situação - carecia de um grupo de funcionários eficientes que mantivesse a máquina pública funcionando, mas também precisava empregar os filhos das elites locais. Assim, parece-nos que existiam espaços no serviço público para indivíduos que, mesmo que o acesso à burocracia tenha sido garantido (ou facilitado) pelas relações familiares que possuía, portassem qualidades que os aproximavam de uma meritocracia (Souza, 2002).

Sendo na sua grande maioria alienígenas, os Presidentes da Província tinham a difícil tarefa de executar a gestão política e administrativa de suas províncias. Como a enorme maioria dos Presidentes de Província eram elementos provenientes de outras regiões do Brasil, o papel dos secretários de governo e dos chefes de seção era fundamental, pois eram eles que conheciam o funcionamento de toda a administração, recebiam ofícios e despachavam dezenas de outros diariamente e detinham o conhecimento de informações preciosas, podendo, assim, imprimir influência nas decisões do chefe palaciano. Isso ainda acrescentando que ao longo do século XIX as tarefas administrativas aumentaram consideravelmente, com a gestão (mesmo que precária) dos fluxos imigratórios, do controle da escravaria (e dos senhores), da administração das fronteiras, melhorias das condições de circulação de pessoas e mercadorias (estradas, pontes, navegação), etc.

Como já dissemos, em abril de 1868, Aurélio foi provido na burocracia rio-grandense como amanuense da Secretaria de Governo, permanecendo neste cargo até $1871^{42}$. Em 23.08.1871 foi promovido para $2^{\circ}$ oficial e em 03.01 .1876 para $1^{\circ}$. Entre os anos de 1877 a $1880 \mathrm{e}$ 1885 a 1886 atuou como Oficial de Gabinete da Secretaria de Governo, assumindo a diretoria da $4^{\mathrm{a}}$ seção em $15.12 .1877(1877 / 1878)^{43} \mathrm{e}$

\footnotetext{
${ }^{42}$ Provisão de 06.04.1868. AHRS - Fazenda, códices F-336 a F-353.

${ }^{43}$ Nomeado para exercer o cargo no lugar de Francisco Pereira da Silva Lisboa, em licença de saúde.
} 
da $2^{\mathrm{a}}$ em 01.07.1878 (1879/1885)44. Daí até 1892 não encontramos registros de promoções, mas quando em 17 de junho de 1892, os republicanos deram entrada no Palácio do Governo, com Júlio de Castilhos à frente, o primeiro ato deste foi chamar Aurélio de Bittencourt e, juntamente com o vice-presidente Victorino Monteiro, encerraram-se no gabinete da Presidência.

Com o passar dos anos, Aurélio foi tornando-se elemento chave na burocracia e política local, pois, conforme as autoridades, preenchia várias características indissociáveis de um cargo de confiança: "Grande inteligência, infatigável atividade e perfeita discrição"45. Na ocasião de sua morte, em 23 de agosto de 1919, Aurélio foi cercado de homenagens e palavras elogiosas que apontavam a falta que o mesmo faria ao serviço público e o vazio que deixava na esfera privada dos governantes.

Esta inserção profissional de Aurélio nos alerta para a carência que temos de pesquisas sobre o funcionalismo público, especialmente no período anterior a proclamação da república. Na já citada lista de qualificação de votantes da Paróquia de Nossa Senhora do Rosário de Porto Alegre, de 1880, encontramos 1.450 nomes e destes 148 eram funcionários públicos, mais de $10 \%$ do total, o que demonstra a relevância destes trabalhadores para o entendimento do período e a concentração dos mesmos na capital provincial ${ }^{46}$. Faltam pesquisas sobre trajetórias profissionais ligadas à burocracia, as formas de recrutamento do corpo burocrático e a utilização da inserção nesse espaço como estratégia de mobilidade social.

Não estamos com isto advogando existir uma profissionalização funcional entre os servidores administrativos provinciais. Notemos no recrutamento de nosso personagem, em 1868, que ele teve de passar por um exame de admissão ao serviço público, conforme determinava o regulamento naquele ano aprovado. Talvez premido por crescentes demandas de mobilidade social, vindas de setores remediados e muitos dos quais de famílias egressas do cativeiro, mas também tendo de dar conta da gestão administrativa e política provincial, o Presidente da

\footnotetext{
${ }^{44}$ Aurélio sofreu uma "derrubada" do cargo público em 1885 (IHGRS - Pasta 2 - Estado e Anexos).

${ }^{45}$ Relatório com que o Sr. Dr. Felisberto Pereira da Silva passou a administração da província de São Pedro do Rio Grande do Sul ao Exmo. Sr. Dr. Carlos Thompson Flores, no dia 19 de Julho de 1879. Tipografia da Livraria Americana, Pelotas, 1880.

${ }^{46}$ Uma das fontes possíveis de pesquisa que nos servem para perceber trajetórias e elaborar uma espécie de cartografia dos funcionários provinciais são os chatíssimos registros de pagamentos funcionais produzidos pelos órgãos fazendários. Trata-se de fonte muito rica: nela encontramos desde o provimento dos funcionários, suas progressões profissionais, suas remunerações, suas exonerações, suas aposentadorias e falecimentos.
} 
Província condicionou o acesso ao corpo de funcionários de amanuenses e segundos oficiais a aprovação em seleção pública.

Claro que, conforme já apontamos, tratava-se de uma sociedade permeada de uma cultura relacional e, portanto, no currículo do candidato eram valorizadas as suas habilidades intelectuais e relacionais, seu patrimônio cultural e sócio-familar. ${ }^{47}$ No artigo 11 do regulamento em questão, já citado, está explícito que os candidatos deveriam apresentar suas petições ao Presidente da Província, "acompanhadas de certidão de idade, folha corrida e quaisquer outros documentos que possam exibir em abono de seu procedimento e capacidade". Esses outros documentos, provavelmente, eram cartas de apresentação e recomendação, que apresentavam o candidato, ou seja, o sustentavam o seu merecimento não só individual, mas familiar, ao pleito. Não que não existisse uma valorização das capacidades profissionais dos candidatos eventuais, mas elas não eram dissociadas de uma necessária descrição precisa do espaço relacional do candidato. (Gribaudi, 2009, p. 24)

Mas mesmo que as forças armadas pudessem ser áreas importantes de recrutamento social de pessoal administrativo, e daí o Tenente Hypólito Simas de Bittencourt poderia auxiliar seu filho nesta demanda, consideramos que também contou fortemente aqui as relações forjadas pelo próprio Aurélio nessa sua estada em Porto Alegre e o capital relacional advindo da parte familiar de sua tia paterna, Leocádia.

Achar o testamento ditado em 22 de março de 1887, em sua casa no centro de Porto Alegre, pela viúva Leocádia Virgínia de Castro foi um prêmio e tanto. O texto desse documento trouxe para a pesquisa um sobrenome bastante familiar para quem investiga a capital da Província sulina. Leocádia era viúva de Luiz Beltrão de Miranda e Castro e deixou legados a um parente de seu falecido marido, Antonio Pedro de Miranda e Castro "morador em Rio Grande". Antonio Pedro, conforme já mencionamos, era funcionário da Alfândega de Uruguaiana, mas absolutamente não era o único membro dessa família a constar na

\footnotetext{
${ }^{47}$ Agradecemos ao historiador Luís Augusto Ebling Farinatti a recomendação de um texto que muito nos ajudou a pensar esta questão do significado do funcionalismo nos oitocentos (Gribaudi, 2009). Esse autor discute a "história do Estado e suas administrações na época contemporânea", debatendo os modelos historiográficos baseados numa "interpretação rígida e teleológica" do modelo weberiano. Ele questiona que, apesar das renovações dos últimos tempos, poucos investimentos foram feitos para desvelar as "fisionomias sociais" dos milhares de funcionários que faziam funcionar concretamente as administrações e captar as diferenças na sua composição e formas de recrutamento.
} 
folha de pagamento provincial. Ao contrário, com o perdão da palavra, pululavam Mirandas e Castros no funcionalismo público!

Investigando a França no século XIX, Maurizio Gribaudi (2009: p. 11) explica que o retrato que emerge "é o de um mundo altamente hierarquizado e dominado por famílias bem enraizadas nos postos mais altos da administração". Essas famílias transmitiam aos seus integrantes e a círculos próximos uma certa bagagem, composta das habilidades necessárias ao exercício das atividades burocráticas, conectada com um espaço relacional interligado com a esfera pública.

Fazendo um levantamento não muito exaustivo dos registros de pagamentos da fazenda provincial, encontramos vários membros desta família, encastelados no corpo de funcionários:

- Alfredo de Miranda e Castro (nomeado Praticante da Secretaria de Governo por Provisão de 31.03.1856, ainda em 1887 consta como colaborador da mesma repartição);

- João Capistrano de Miranda e Castro (provido em 17.02.1848 como Inspetor da Administração da Fazenda Provincial, aparece em 1857 como Contador Chefe e em 1859 como Diretor Geral, aposentado por Ato e título de 06.07.1878);

- João Capistrano de Miranda e Castro Filho (provisão para o cargo de amanuense da Secretaria de Governo em 02.03.1857, onde atuava em 14.04.1848 como $2^{\circ}$ oficial);

- Joaquim Pedro de Miranda e Castro (Contínuo da Secretaria de Governo, nomeado em 04.02.1886);

- José de Miranda e Castro (Oficial da Secretaria de Governo por Provisão de 19.10.1833, Chefe da $2^{\text {a }}$ Seção, em 06.07.1850, Oficial de Gabinete em 03.01.1867, Chefe de Seção em 06.03.1857, Oficial Maior 23.08.1871. Faleceu em 30.01.1875) $)^{48}$.

Temos ainda o Dr. Francisco Pedro de Miranda e Castro, advogado formado pela Faculdade de Direito de São Paulo, deputado provincial em 1877 e 1878, filho de João Capistrano de Miranda e Castro, o qual encontramos como Promotor Público em 1868 e 1869, pelo menos.

Mas se focarmos especificamente a segunda metade do século XIX, o patriarca da família Miranda e Castro, certamente, era João Capistrano de Miranda e Castro, já citado acima por sua inserção na Fazenda Provincial. Na lista dos Votantes da Paróquia do Rosário, de 1880, ele aparece com o número 141, com 76 anos, já viúvo, empregado

${ }^{48}$ AHRS - Fazenda: F-221 a 224, F-248, F-249, F-303, F-316 a F-342, F-353, F-354. 
aposentado, filho de Francisco Pedro de Miranda e Castro, morador na rua do Riachuelo, com renda conhecida de 4:800\$49.

O Dr. João nasceu em Desterro, em Santa Catarina, atual Florianópolis, diplomou-se em Direito na Faculdade de São Paulo, "e em 1836 já estava em Porto Alegre, onde seu pai, Francisco Pedro de Miranda e Castro, desempenhou funções municipais, especialmente como Procurador da Câmara" (Franco, 2010, p. 59). Como vemos, o pai Francisco Pedro já tinha proximidade com a esfera pública municipal. Aliás, o Capitão Francisco Pedro de Miranda e Castro foi vitimado pela epidemia do cólera que grassou em Porto Alegre em 1855 e 1856, falecendo em 3 de janeiro de 1856. No seu registro de óbito consta ter sido enterrado no Cemitério da Misericórdia, com 75 anos de idade, natural de Santa Catarina e já viúvo de Rita Maria de Assunção ${ }^{50}$.

O filho do Capitão Francisco Pedro continuou a tradição paterna de uma inserção íntima com o governo e sua administração, mas chegou bem mais longe que o pai. Ele assumiu por duas vezes interinamente a Presidência da Província, já que atuava como Vice-Presidente da mesma, de 02.03.1848 a 10.04.1848 e de 29.08.1870 a 04.11.1870. Além disso, ligado ao Partido Conservador, foi Deputado Provincial em 1846 e 1847,1850 e 1851,1853 a $1857^{51}$.

Esta família natural de Santa Catarina (assim como os laços paternos de Aurélio), tinha lá suas tradições. O Dr. João Capistrano de Miranda e Castro morreu em 11.11.1882, viúvo como seu pai e também em uma idade similar, 77 anos. Foi descrito como branco, a causa morte foi o amolecimento cerebral, mas preferiu ser velado na Igreja do Rosário ${ }^{52}$.

\footnotetext{
${ }^{49}$ Dos 1.304 votantes que trazem explicitamente esse dado, apenas 39 deles tem renda conhecida acima de 3 contos de réis, o equivalente a cerca de 3\% do total. Sobre as eleições no Brasil, ver: Graham (1997), Carvalho (1997), Dias (1998), Klein (1995), Costa, 2006.

${ }^{50}$ AHCMPA - Livro $n^{0} 8$ de óbitos de Livres da Catedral, folha 54v. Em 3 de setembro do ano anterior (1855), o Capitão Francisco de Pedro, já de cama, pediu que Antonio Pedro de Miranda e Castro redigisse e assinasse a seu rogo uma carta de alforria a dois de seus escravos, Cezária e seu filho Aprigio (de 10 anos de idade). Na carta que foi registrada em cartório no dia seguinte ao falecimento do Capitão ele concedia a liberdade a Cezária mediante o pagamento de $600 \$(400 \$$ à vista e $200 \$$ em três meses) e alforriava Aprigio "em atenção ao amor de criação que tenho, $e$ aos bons serviços que sua mãe me tem sempre prestado". APERS - $2^{\circ}$ Tabelionato, Livro 67 de Transmissões e Notas, folha 47.

${ }^{51}$ AHRS - Eleições, EL-01. Ver: Relatório com que João Sertório passou a administração para João Capistrano de Miranda e Castro, em 29.08.1870; Relatório com que o Exmo. Sr. Dr. João Capistrano de Miranda e Castro, $1^{\circ}$ Vice-presidente da Província, passou a administração da mesma ao Exmo. Sr. Conselheiro Francisco Xavier Pinto Lima, em 04.11.1870; e o Relatório do Vice-Presidente da Província João Capistrano de Miranda e Castro à abertura da Assembleia Legislativa Provincial em 4 de março de 1848.

${ }^{52}$ AHCMPA - Livro de Óbitos de livres do Rosário, $n^{\circ}$ 9, folha 95v. Foi encomendado pelo Padre Vicente Sebastiam Wolfenbuttel.
} 
Sabendo destas relações seria ingenuidade não inseri-las como capital usado por Aurélio para seu ingresso no funcionalismo público provincial. Mas, ao mesmo tempo, considerar que seu ingresso foi unicamente consequência desse apadrinhamento nos parece muito simplista. Não podemos cair na armadilha da ilusão biográfica e pensar que a trajetória de Aurélio, já que sabemos como terminou, esteve sempre fadada ao sucesso. Os setores sociais médios procuravam jogar com as cartas que possuíam, mesclando talentos pessoais com patrimônios relacionais (individuais e familiares). Mas era um jogo que não se jogava sozinho, mas em acirrada tensão com outros competidores, também munidos de capitais e recursos muito similares.

Como se evidencia em nossas pesquisas, e já vimos brevemente, Aurélio Viríssimo de Bittencourt possuía grandes habilidades relacionais, as quais usava plenamente em um esforço de ampliar seu leque de sociabilidades. Nesse aspecto temos que considerar que sua grande devoção católica muito ajudou, pois a fé movia importantes espaços relacionais na capital da Província sulina. Não que as hierarquias sociais se diluíssem nas irmandades e igrejas, mas nesses espaços indivíduos muito diferentes econômica, política e etnicamente se conheciam, entretinham relações diversas e, ocasionalmente, se aliavam por motivos diversos. Se escravos e seus senhores muitas vezes compartilhavam devoções e frequentavam os mesmos espaços litúrgicos, certamente isso ocorria cotidianamente entre os grandes e pequenos homens, os grandes e pequenos funcionários. Talvez mal se cumprimentassem nas ruas e escritórios, mas nas Irmandades eram todos irmãos de fé e sociabilidade, numa comunidade que, mesmo que fictícia ou simbólica, podia gestar laços mais ou menos duradouros.

Temos uma informação muito superficial, que aponta Francisco Pedro de Miranda e Castro, pai do Dr. João Capistrano, como escrivão da mesa da Irmandade de Nossa Senhora da Conceição, em $1830^{53}$. Pelo visto os Miranda e Castro e os Bittencourt eram da mesma cepa religiosa, de forte fervor católico. O registro de óbito do Dr. João de Capistrano, entretanto, o insere na Paróquia do Rosário e nesse lócus encontramos efetivamente o encontro entre ele e o nosso personagem principal.

Talvez o dia 2 de fevereiro de 1871 tenha sido daqueles dias quase insuportáveis do verão porto-alegrense. Torcemos para que o interior

${ }^{53}$ AHRS - Autoridades Religiosas, Maço 14 Caixa AR 07. Ata da entrega dos hábitos em 2 de fevereiro de 1871 . 
da Igreja do Rosário tivesse uma temperatura mais agradável, o que era possível já que eram apenas 8 horas da manhã quando os irmãos da Irmandade de Nossa Senhora do Rosário, vestidos com suas opas (capas) foram avisados da chegada de Sua Exa. Reverendíssima o Sr. Bispo Diocesano D. Sebastião Dias Laranjeira, "acompanhado de membros do Cabido e diversos sacerdotes". O Bispo Diocesano foi dignamente recepcionado à porta da Igreja e conduzido até o altar, pelos 41 irmãos que antecipadamente estavam reunidos no consistório do templo. Por questões óbvias de espaço listaremos apenas os quatro primeiros que aparecem na ata que registrou esse momento solene: Lourenço Antonio da Soledade, Antonio Feliciano Gonçalves, Aurélio Viríssmo de Bittencourt e o Dr. João Capistrano de Miranda e Castro. Lado a lado, vestidos dignamente com suas capas, estava o bacharel que até novembro do ano anterior exercera interinamente a presidência da Província e o jovem amanuense da Secretaria do Governo. O Bispo ocupou o lugar anteriormente reservado "ao lado do Evangelho colocado sobre o altar-mor", abençoou e distribuiu os hábitos aos:

Irmãos que tinham declarado querer pertencer a Archi-confraria de N. Sra. do Rosário, dignidade a que havia sido elevada a Irmandade, [...] em primeiro lugar o Juiz Lourenço Antonio da Soledade, e Dr. João Capistrano de Miranda e Castro, em segundo o Juiz, por benção, Antonio Feliciano Gonçalves, e o escrivão Aurélio Virissimo de Bittencourt, seguindo-se depois os demais irmãos, a dois e dois. Recebendo todos os competentes hábitos, vieram ao consistório para com eles revestirem-se, e depois voltaram em turmas de dois a receber das mãos de S. Exa. Reverendíssima o Santíssimo Rosário e a medalha de Nossa Senhora do Rosário pendente de um laço de fita azul. [grifos nossos]

Não nos estenderemos na descrição deste belo ritual, mas “revestidos todos os irmãos de suas novas insígnias", assistiram a uma Missa rezada pelo Bispo Diocesano, "ouvida com o mais religioso respeito", o qual depois "fez uma breve alocução aos irmãos confrades, mostrando a importância do voto que tinham acabado de contrair, a imensa responsabilidade que sobre eles pesava e incitando-os a dedicar-se com todo o esforço ao serviço da Mãe Santíssima do Rosário que os encheria de bens e felicidades, sobre a terra." Cumprindo sua sina de burocrata e usando dos dotes demonstrados quando do concurso público para amanuense feito três anos antes (que exigia boa letra e conhecimento 
da gramática portuguesa), o secretário ou escrivão Aurélio Viríssimo de Bitttencourt redigiu a ata solene de entrega dos hábitos.

No período republicano, a correspondência trocada entre Aurélio e Júlio de Castilhos (e aí chamamos a atenção para o arquivo particular de Júlio Prates de Castilhos, custodiado pelo AHRS) revela que no dia-a-dia da vida palaciana a figura de Aurélio foi fundamental, uma vez que ele permanecia a maior parte do tempo na secretaria da presidência enquanto Castilhos mantinha-se mais afastado em sua chácara ${ }^{54}$. A proeminência do burocrata também estava assentada na liderança que ele possuía sobre os pequenos empregados das secretarias, a sua aproximação com a vida religiosa na capital e a sua ascendência entre os populares.

Retornando ao texto do implicante Múcio Teixeira - com o qual introduzimos este artigo -, vemos que ele não poupou Aurélio de sarcasmos, mesmo cometendo alguns deslizes propositais com relação aos fatos, muitos dos quais ele presenciou. Escreveu Múcio:

Como se vê, é um negro de clara sorte na terra e límpida estrela no céu. Educado, nessa humilde condição, nos mais rigorosos princípios religiosos, foi tão convenientemente instruído, que muito cedo conquistou a estima e consideração das pessoas mais gradas da nossa sociedade, que o receberam sem escrúpulos, numa época e meio em que predominavam os preconceitos de cores. Convivendo na intimidade dos mais distintos moços do Parthenon, com eles colaborou na sua Revista, de onde passou para os jornais diários, até chegar a ser o redator-chefe do Jornal do Comércio, que era a primeira folha do Rio Grande do Sul (Teixeira, 1920, 214-219).

A última frase desta citação parece dar a Aurélio uma posição secundária ou subalterna na criação e funcionamento do Parthenon Literário, o que não ocorreu de fato. Em 18 de junho de 1868, num dia frio do inverno porto alegrense, cerca de 20 pessoas, entre elas Aurélio Viríssimo de Bittencourt, dirigiram-se à Rua Nova (atual Andrade Neves), para a sessão de instalação da Sociedade Parthenon Literário - uma das associações de maior duração (1868-1885) e versatilidade existente no estado antes da República (Hessel, 1976, p. 47; Silveira, 2008, p. 107). Além de ser escolhido para a diretoria provisória como $2^{\circ}$ secretário (sempre lidando com papéis e arquivos!), coube a Aurélio, dois dias depois, redigir um folhetim, publicado no Jornal do Comércio,

\footnotetext{
${ }^{54}$ AHRS - Arquivo Particular de Aurélio Viríssimo de Bittencourt.
} 
tratando da instalação do Parthenon - que tinha entre as suas principais lideranças o jovem Apolinário Porto Alegre, amigo de Aurélio e dono da residência onde a referida sessão acontecera ${ }^{55}$.

Segundo Cássia Silveira (2008, p. 178) em 14 de setembro do ano seguinte Aurélio comunicou, através do jornal liberal A Reforma, sua renúncia ao cargo de secretário do Parthenon e o abandono da própria associação. Esta passagem nos remete novamente aos anos finais da década de 1860, quando Aurélio parecia dedicar-se com afinco em entreter relações de variadas formas, inserindo-se favoravelmente na vida associativa da capital da Província.

Data da mesma época da criação do Parthenon uma passagem bastante significativa na vida de Aurélio. Na noite de 26 de dezembro de 1868, às 20 horas, Aurélio casou-se com Joana Joaquina do Nascimento, filha natural de Joaquim Manuel do Nascimento e Maria Magdalena da Conceição. Na ocasião, Aurélio foi apadrinhado por seu companheiro de Parthenon, de Sociedade União e da Igreja do Rosário Apolinário Porto Alegre e pelo Capitão Francisco Coelho Barreto. Se as proximidades de Aurélio com Apolinário são mais óbvias (e vão mantêlos próximos ainda no período republicano), as com o Capitão Barreto parecem baseadas no espaço profissional de ambos. Francisco Coelho Barreto também era empregado de carreira da Secretaria do Governo: Oficial (nomeado por Provisão de 02.07.1835), $1^{\circ}$ Oficial (Provisão de 06.03.1857), Chefe da Seção do Expediente da Repartição de Obras Públicas Provinciais (Ofício da Presidência da Província de 02.03.1858)

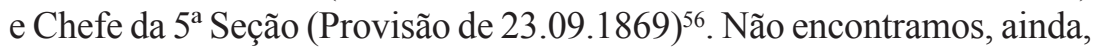
outros vínculos entre esses dois indivíduos, mas quem sabe Aurélio o conheceu, antes de entrar no serviço público provincial, quando foi obrigado a trabalhar gratuitamente na secretaria por espaço de 8 dias. [artigo 11]

É interessante perceber aqui que Aurélio escolheu como parceira alguém de sua própria situação social e étnica, pois ambos eram filhos naturais, frutos de relações ilegítimas, e registrados como pardos nos assentamentos de óbitos. A cerimônia foi realizada pelo Reverendo Vigário José Ignácio de Carvalho e Freitas, na Igreja do Rosário em

\footnotetext{
${ }^{55}$ A Sociedade não serviu somente para veicular textos, poesias, contos ou ensaios de seus colaboradores. Entre outras iniciativas, seus integrantes criaram uma escola noturna gratuita (1872-1885), um museu e uma biblioteca própria, que chegou a ter mais de 6.000 volumes, alforriaram escravos, encenaram peças teatrais, propagaram os ideais abolicionistas e republicanos, assim como instituíram a pesquisa bibliográfica, resgatando o registro das lendas e tradições sul rio-grandenses (Cesar, 1956, p. 49).

${ }^{56}$ AHRS - Fazenda - F-221 a 227, F-316 a 338.
} 
Porto Alegre, templo principal da devoção católica da população negra local ${ }^{57}$.

Em 26 de fevereiro de 1904 o Presidente honorário da Sociedade Portuguesa de Beneficência José Francisco da Silva Nunes redigiu um resumo histórico desta agremiação, visando comemorar os cem anos de fundação da mesma ${ }^{58}$. Silva Nunes rememora que os sócios da Beneficência eram atendidos, nos primeiros anos, em uma sala especial localizada na Santa Casa de Misericórdia. Em 1858 foi comprado um prédio na Rua da Figueira, para onde no ano seguinte foram transferidos os doentes. Em 1863 dois prédios contíguos ao primeiro foram comprados, dando-se a instalação de duas enfermarias - uma de alopatia e outra de homeopatia. A construção do hospital da Beneficência começou a materializar-se com o lançamento da pedra fundamental em 29.06.1867. O texto de Silva Nunes desdobra-se cronologicamente e em 1868 ele menciona algumas atividades que permitiram a inauguração do hospital em 29.06.1870.

Em benefício do novo hospital e durante a construção do mesmo, deu muitos espetáculos uma sociedade dramática particular denominada Gymnasio do Commercio, sendo amadores os Senhores Joaquim P. Vieira, Antonio de Azevedo Lima, Hygino Lopes Duro, Luiz Francisco Cavalcanti de Albuquerque, Aurélio Veríssimo de Bittencourt, Theodolino Antonio da Rosa, Augusto Teixeira Cardoso, Luiz Franklin de Vasconcellos Ferreira, Joaquim Francisco de Souza Motta e outros. A Diretoria e Conselho encarregavamse da passagem dos bilhetes, o que produzia mais valiosa receita. Também tomavam a seu cargo os lugares de porteiros. Os distintos amadores acima citado grandes auxiliares para a construção do nosso hospital, foram todos agraciados com os diplomas de sócios

\footnotetext{
${ }^{57} \mathrm{O}$ casal Aurélio e Joana teve 4 filhos: Sérgio Aurélio de Bittencourt (nascido em 07.10.1869), Adelina Lydia de Bittencourt (1870), Olímpia Augusta de Bittencourt Campos (26.07.1872), Aurélio Viríssimo de Bittencourt Júnior (28 de fevereiro de 1874) e Maria (25.03.1878). O destino é cruel e atropela os planejamentos individuais e familiares. Como já mencionamos na citação de Múcio Teixeira acima, Aurélio Júnior, que foi enviado por seu pai para São Paulo, onde se formou em Direito, depois assumindo em Porto Alegre como juiz na $2^{\mathrm{a}}$ Vara de Órfãos, morreu prematuramente em 30 de julho de 1910. Malograram-se os planos e investimentos do já velho Aurélio com relação a seu homônimo primogênito, ficando ainda como tutor do único filho do mesmo, o futuro poeta, catedrático, advogado e integralista Dario de Bittencourt. Dario não ficou com sua mãe Maria da Glória Quilião de Bittencourt, pois ela e seu pai se divorciaram em 1906, quando estavam casados a apenas dois anos e ele tinha cinco anos de idade, ficando " $\mathrm{em}$ poder e sob a administração paterna". AHCMPA - Livro 3 da Igreja do Rosário, p. 97v. APERS - Superior Tribunal do Estado do RGS - maço 18, auto 183; APERS - $2^{\circ}$ Cartório do Cível, 1895, auto 589, maço 18 (inventário). Joana faleceu em 1894. Ver: Cardozo, 2011; Santos, 2008. ${ }^{58}$ SBPPA/MUHM - Resumo Histórico da Sociedade Portuguesa de Beneficência - Porto Alegre $-1854 / 1904$.
} 
benfeitores, como preito de agradecimento da Sociedade. Bem o mereceram! A Beneficência apenas pagava as despesas de teatro, luzes e musica, correndo todas as outras despesas dos espetáculos por conta daqueles benfeitores. [Grifos nossos]

O incansável Aurélio reaparece neste texto em mais uma de suas faces, a de ator amador. Tinha uns 19 anos na época e não tinha capital financeiro suficiente para aproximar-se das sociedades que the dariam prestígio, mas graças a suas atitudes despojadas de auxílio pôde aproximar-se destas agremiações e adquirir através delas algum prestígio. Não estamos com isso caindo na armadilha funcionalista de atribuir intenções calculistas a cada gesto dos indivíduos enfocados, mas também seria ingênuo pensar nas ações sociais como destituídas de certa dose de artimanha.

Foram redimensionadas nos últimos anos as pesquisas que objetivam analisar trajetórias individuais. $\mathrm{O}$ enfoque foi deslocado do sujeito em si para as suas relações, suas inserções em redes diversas, as composições de alianças (mesmo instáveis e temporárias). Segundo Jacques Revel:

[...] a escolha do individual não é vista [...] como contraditória à do social: ela deve tornar possível uma abordagem diferente deste, ao acompanhar o fio de um destino particular - de um homem, de um grupo de homens - e, com ela, a multiplicidade dos espaços e dos tempos, a meada das relações nas quais ele se inscreve.

Mas dentre várias outras indagações, resta-nos ainda uma: será a trajetória de Aurélio Viríssimo de Bittencourt suficientemente representativa para a análise de seus contemporâneos negros? Muitos responderiam que ele é um caso absolutamente atípico e sua excepcionalidade em termos de mobilidade social não lhe delegariam possibilidades de entendimento de outros de seus pares. Entretanto, ponderamos que desprezar Aurélio como representativo das experiências de vidas de vários outros indivíduos como ele, talvez seja deixar-se enganar pela ilusão biográfica de que fala Bourdieu, compreendendo a sua trajetória como algo linear, fadada ao sucesso profissional desde o seu prelúdio. Mesmo que as trajetórias não devam ser compreendidas como "um todo, um conjunto coerente e orientado, que pode e deve ser apreendido como expressão unitária de urna 'intenção' subjetiva e objetiva, de um projeto" (Bourdieu, 1996. p. 184), isso não exime os indivíduos estudados de agirem de acordo com investimentos 
e estratégias, na maioria das vezes familiares. Como as trajetórias individuais não são mais vistas sob a perspectiva do estanque e do absolutamente autônomo, itinerários como esse de Aurélio certamente nos descortinam o entrecruzamento de inúmeros outros percursos biográficos, interdependentes, mas com itinerários dessemelhantes.

Nos cercamos, neste artigo, de vestígios documentais diversos para abordar algumas das vicissitudes biográficas do pardo Aurélio Viríssimo de Bittencourt, da meada das relações nas quais estava inserido. (LEVI, 2000) A idéia foi justamente proceder a uma submersão em nomes de indivíduos e de agremiações, procurando dar materialidade a sua trajetória profissional, associativa, relacional.

\section{Abreviaturas}

AHCMPA - Arquivo Histórico da Cúria Metropolitana de Porto Alegre.

AHEx - Arquivo Histórico do Exército (RJ).

AHRS - Arquivo Histórico do Estado do Rio Grande do Sul.

AMRJ - Arquivo da Marinha (Rio de Janeiro).

ANRJ - Arquivo Nacional do Rio de Janeiro.

APAVB - Arquivo Particular de Aurélio Viríssimo de Bittencourt.

APERS - Arquivo Público do Estado do Rio Grande do Sul.

IHGRS - Instituto Histórico e Geográfico do Rio Grande do Sul.

SBPPA/MUHM - Acervo da Sociedade de Beneficência Portuguesa de Porto Alegre/ Museu de História da Medicina.

\section{Referências}

AITA, Carmen; AXL, Gunter; ARAÚJO, Vladimir (Org.). Parlamentares Gaúchos das Cortes de Lisboa aos nossos dias - 1821-1996. Porto Alegre, Assembleia Legislativa do Estado do Rio Grande do Sul, 1996.

ALMEIDA, Antonio da Rocha. Hypólito Simas de Bittencourt. In: Jornal Correio do Povo. 16 dez. 1962.

ARIAS NETO, José Miguel. Em busca da cidadania: praças da Armada Nacional 1867-1910. Tese (Doutorado em História) - Universidade de São Paulo, São Paulo, 2001.

BAKHTIN, Mikhail. A cultura popular na Idade Média e no Renascimento: o contexto de François Rabelais. São Paulo: Editora Hucitec; Brasília: Editora da Universidade de Brasília, 1993.

BOURDIEU, Pierre. A ilusão biográfica. In: FERREIRA, Marieta de Moraes, AMADO, Janaína (Org.). Usos \& Abusos da História Oral. Rio de Janeiro: FGV, 1996. p. 183-191. BURKE, Peter. Hibridismo Cultural. São Leopoldo: Editora UNISINOS, 2003. 
CARDOZO, José Carlos da Silva. Enredos tutelares: o Juizado de Órfãos e a (re)organização da família porto-alegrense no início do século XX. Dissertação (Mestrado em História) - Universidade do Vale do Rio dos Sinos, São Leopoldo, 2011.

CARVALHO, Daniela Vallandro de. Entre a solidariedade e a animosidade: as relações interétnicas populares (Santa Maria - 1885-1915). São Leopoldo: Universidade do Vale do Rio dos Sinos, 2005.

CARVALHO, José Murilo de. Dimensiones de la Ciudadanía em el Brasil del Siglo XIX. In: SABATO, Hilda. Ciudadania política y formacion de las naciones. Prespectivas politicas de América Latina. México: Fondo de Cultura Economica, 1997.

CARVALHO, José Murilo. Rui Barbosa e a razão clientelista. Dados, Rio de Janeiro, v. 43 , n. $1,2000$.

CASTRO, Celso; IZECKSOHN, Vitor; KRAAY, Hendrik (Org.). Nova história militar brasileira. Rio de Janeiro: FGV, 2004.

CESAR, Guilhermino. História da Literatura do RS (1737-1902). Porto Alegre: Globo, 1956.

COSTA, Miguel Angelo Silva da. Entre a flor da sociedade e a escória da população: a experiência de homens livres pobres no eleitorado de Rio Pardo (1850-1880). Dissertação (Mestrado em História) - Universidade do Vale do Rio dos Sinos, São Leopoldo, 2006.

COSTA, Miguel Angelo Silva da. Entre a "intolerância política" e a "sede ardente de mando": família, poder e facções no tempo dos cunhados José Joaquim de Andrade Neves e João Luis Gomes da Silva (1845-1870). Tese (Doutorado em História) Universidade do Vale do Rio dos Sinos, São Leopoldo, 2011.

DAVIS, Natalie Zemon. O retorno de Martin Guerre. Rio de Janeiro, Paz e Terra, 1987.

DIAS, Maria Odila Leite da. Sociabilidades sem História: votantes pobres no Império, 1824-1881. In: FREITAS, Marcos Cezar de (Org.). Historiografia brasileira em perspectiva. São Paulo: Contexto, 1998.

ELIAS, Norbert. O processo civilizatório. Rio de Janeiro: Zahar, 1993. Vol. 2: Formação do estado e Civilização.

FRAGOSO, João Luís Ribeiro. Afogando em nomes: temas e experiências em história econômica. Topoi, Rio de Janeiro, p. 41-70, set. 2002.

FRANCO, Sérgio da Costa. Dicionário político do RGS - 1821/1937. Porto Alegre: Suliani Letra \& Vida, 2010.

FRANCO, Sérgio da Costa. Gente e coisas da Fronteira Sul: ensaios históricos. Porto Alegre: Sulina, 2001.

GINZBURG, Carlo. Provas e possibilidades à margem de "Il ritorno de Martin Guerre", de Natalie Davis. A micro-história e outros ensaios. Lisboa: DIFEL; Rio de Janeiro: Bertrand Brasil, 1991.

GRAHAM, Richard. Clientelismo e política no Brasil do Século XIX. Rio de Janeiro: Editora UFRJ, 1997.

GRIBAUDI, Maurizio. Le savoir des relations: liens et racines sociales d'une administration dans la France du xixe siècle. Le Mouvement Social, 228, n. 3, p. 9-38, 2009.

GRINBERG, Keila. O fiador dos brasileiros: cidadania, escravidão e direito civil no tempo de Antonio Pereira Rebouças. Rio de Janeiro: Civilização Brasileira, 2002. 
GRUZINSKI, Serge. O pensamento mestiço. São Paulo: Companhia das Letras, 2001.

HESSEL, F. Lothar e outros. Partenon Literário e sua obra. Porto Alegre: Flama, Instituto Estadual do Livro, 1976.

HESSEL, Lothar. Teatro no Rio Grande do Sul. Porto Alegre: Ed. da Universidade/ UFRGS, 1999.

IMÍZCOZ, José María. Patronos y mediadores. Redes familiares en la Monarquía y patronazgo en la aldea: la hegemonia de las elites baztanesas en el siglo XVIII. In: IMÍZCOZ, José Maria (Org.). Redes familiares y patronazgo. Aproximación al entramado social del País Vasco y Navarra en el Antiguo Régimen (siglos XV-XIX). Bilbao: Universidad del País Vasco, 2001. p. 225-261.

JEHA, Silvana Cassab. A galera heterogênea: naturalidade, trajetória e cultura dos recrutas e marinheiros da Armada Nacional e Imperial do Brasil, c.1822-c.1854. Tese (Doutorado em História) - Pontifícia Universidade Católica do Rio de Janeiro, Rio de Janeiro, 2011.

KLEIN, Herbert S. A participação política no Brasil do século XIX: os votantes de São Paulo em 1880. DADOS - Revista de Ciências Sociais, Rio de Janeiro, v. 38, n. 3, p. 527-544, 1995.

LEVI, Giovanni. A herança imaterial: trajetória de um exorcista no Piemonte do século XVII. Rio de Janeiro: Civilização Brasileira, 2000.

LIMA, Henrique Espada Rodrigues. A micro história italiana: escalas, indícios e singularidades. Rio de Janeiro: Civilização Brasileira, 2006.

MACHADO, Maria Helena. O plano e o pânico. Os movimentos sociais na década da abolição. Rio de Janeiro: Editora UFRJ, EDUSP, 1994.

MATTOS, Hebe Maria. Escravidão e cidadania no Brasil Monárquico. Rio de Janeiro: Jorge Zahar Editor, 2000.

MOREIRA, Luciano da Silva. Tipografias e espaço público na Província de Minas Gerais (1828-1842). In: SEMINÁRIO BRASILEIRO SOBRE LIVRO E HISTÓRIA EDITORIAL, I., 2004. Disponível em: <http://www.livroehistoriaeditorial.pro.br>.

MOREIRA, Paulo Roberto Staudt. Fragmentos de um enredo: Nascimento, primeiras letras e outras vivências de uma criança parda numa vila fronteiriça (Aurélio Viríssimo de Bittencourt/Jaguarão, século XIX). In: PAIVA, Eduardo et al. (Org.). Escravidão, mestiçagens, populações e identidades culturais. São Paulo/Belo Horizonte/Vitória da Conquista: ANNABLUME/PPGH UFMG/Edições UESB, 2010. p. 115-138.

MOREIRA, Paulo Roberto Staudt. Os cativos e os homens de bem-experiências negras no espaço urbano. Porto Alegre: Edições EST, 2003.

MOREIRA, Paulo Roberto Staudt. Com ela tem vivido sempre como o cão com o gato Alforria, maternidade e gênero na fronteira meridional In: GOMES, Flávio et al. (Org.). Histórias das mulheres negras: condição feminina, escravidão e pós-emancipação no Brasil, séculos XVIII ao XX Rio de Janeiro: Selo Negro, 2011.

MOURA, Clóvis. Rebeliões da Senzala. 4. ed. Porto Alegre: Mercado Aberto, 1988.

NASCIMENTO, Álvaro. A ressaca da marujada: recrutamento e disciplina na Armada Imperial. Rio de Janeiro: Arquivo Nacional, 2001. 168 p.

OLIVEIRA, Clovis Silveira de. Porto Alegre - A cidade e sua formação. Porto Alegre: Gráfica e Editora Norma, 1985. 
REVEL, Jacques. A história ao rés do chão. In: LEVI, Giovanni. A herança imaterial: trajetória de um exorcista no Piemonte do século XVII. Rio de Janeiro: Civilização Brasileira, 2000.

RIBEIRO, José Iran. “De tão longe para sustentar a honra nacional”: Estado e Nação nas trajetórias dos militares do Exército Imperial brasileiro na Guerra dos Farrapos. Tese (Doutorado em História) - Universidade Federal do Rio de Janeiro, Rio de Janeiro, 2009.

SANTOS, José Antonio dos. O Curriculum Vitae como vestígio do passado. Dario de Bittencourt (1901-1974), uma eminência duplamente parda. In: ANPUH-RS ENCONTRO ESTADUAL DE HISTÓRIA, IX., 2008, Porto Alegre, RS. Vestígios do Passado: a história e suas fontes. São Leopoldo: Editora Oikos, 2008.

SANTOS, José Antônio dos. Intelectuais negros e imprensa no Rio Grande do Sul: uma contribuição ao pensamento social brasileiro. In: SILVA, Gilberto Ferreira da; SANTOS, José Antônio dos; CARNEIRO, Luiz Carlos da Cunha (Org.). RS Negro: cartografias sobre a produção do conhecimento. Porto Alegre: EdiPUCRS, 2008b. p. 83-99.

SCHIMIDT, Benito Bisso. A biografia histórica: o "retorno" do gênero e a noção de "contexto". In: GUAZZELLI, César B.; PETERSEN, Sílvia R. F.; SCHIMIDT, Benito B.; XAVIER, Regina C. L. Questões de teoria e metodologia da história. Porto Alegre: Ed. da Universidade/UFRGS, 2000.

SCHIMIDT, Benito Bisso. Em busca da terra da promissão: a história de dois líderes socialistas. Porto Alegre: Palmarinca/Fumproarte, 2004.

SILVA Jr., Adhemar Lourenço da. As sociedades de socorros mútuos: estratégias privadas e públicas (estudo centrado no Rio Grande do Sul-Brasil, 1854-1940. Tese (Doutorado) - Pontifícia Universidade Católica do Rio Grande do Sul, Porto Alegre, 2004.

SILVEIRA, Cássia Daiane Macedo da. Dois pra lá dois pra cá: o Parthenon Literário e as trocas entre literatura e política na Porto Alegre do século XIX. Dissertação (Mestrado em História) - Universidade Federal do Rio Grande do Sul, Porto Alegre, 2008.

REIS, João José. Domingos Sodré. Um sacerdote africano: escravidão, liberdade e candomblé na Bahia do século XIX. São Paulo: Companhia das Letras, 2008. 461p.

SOUZA, Antônio Cândido de Mello e. Um funcionário da monarquia: ensaio sobre o segundo escalão. Rio de Janeiro: Ouro Sobre Azul, 2002.

SPALDING, Walter. Pequena história de Porto Alegre. Porto Alegre: Sulina, 1967.

TAVARES, Mauro Dillmann. Irmandades, igrejas e devoção no sul do Império do Brasil. São Paulo: UNISINOS/OIKOS, 2008.

TEIXEIRA, Múcio. Os gaúchos. Rio de Janeiro: Livraria Leite Ribeiro, 1920. Vol. 1 e 2.

THOMPSON FLORES, Mariana Flores da Cunha. Contrabando e contrabandistas na Fronteira Oeste do Rio Grande do Sul - 1851-1864. Dissertação (Mestrado em História) - Universidade Federal do Rio Grande do Sul, Porto Alegre, 2007. p. 130-131.

VARGAS, Jonas Moreira. Entre a Paróquia e a Corte: uma análise da elite política no Rio Grande do Sul (1868-1889). Dissertação (Mestrado em História) - Universidade Federal do Rio Grande do Sul, Porto Alegre, 2007.

VENÂNCIO, Renato Pinto. Redes de compadrio em Vila Rica: um estudo de caso. In: ALMEIDA, Cara Maria Carvalho de; OLIVEIRA, Mônica Ribeiro de. Exercícios de micro-história. Rio de Janeiro: Editora FGV, 2009. 
VILLAS-Bôas, Pedro. Notas de Bibliografia Sul-Rio-Grandense. Porto Alegre: A Nação; Instituto Estadual do Livro, 1974. p. 509-510.

WITT, Marcos. A política no Litoral Norte do Rio Grande do Sul: a participação de nacionais e de colonos alemães - 1840/1889. Dissertação (Mestrado) - Universidade do Vale do Rio dos Sinos, São Leopoldo, 2001.

Submetido em 07/02/2014.

Aprovado em 21/07/2014. 